Bull. Chem. Soc. Ethiop. 2019, 33(1), 21-41.

ISSN 1011-3924

(C) 2019 Chemical Society of Ethiopia and The Authors

Printed in Ethiopia

DOI: https://dx.doi.org/10.4314/bcse.v33i1.3

\title{
ASSESSMENT OF THE QUALITY OF BOTTLED WATER MARKETED IN ADDIS ABABA, ETHIOPIA
}

\author{
Elisabet Yilkal, Feleke Zewge* and Bhagwan Singh Chandravanshi
}

Department of Chemistry, College of Natural and Computational Sciences, P. O. Box 1176, Addis Ababa University, Ethiopia

(Received November 4, 2018; Revised January 17, 2018; Accepted January 28, 2019)

\begin{abstract}
The consumption of bottled drinking water has been increasing in the world. But, the quality of bottled water used for human consumption is not subjected to any stringent quality control measure in Ethiopia. The present study was carried out to determine the physicochemical quality parameters of twenty brands of bottled drinking water available in Addis Ababa and to compare with drinking water guidelines set by World Health Organization (WHO) and Compulsory Ethiopia Standards (CES). The samples were collected by random sampling technique. The physicochemical parameters such as $\mathrm{pH}$; TDS and EC; total alkalinity, total hardness, $\left.\mathrm{HCO}_{3}^{-}, \mathrm{Cl}^{-} ; \mathrm{SO}_{4}^{2-}, \mathrm{NO}_{3}^{-}, \mathrm{NO}_{2}^{-}, \mathrm{F}^{-}\right)$and common cations $\left(\mathrm{Ca}^{2+}, \mathrm{Mg}^{2+}, \mathrm{Na}^{+}\right.$, and $\left.\mathrm{K}^{+}\right)$were determined by $\mathrm{pH}$ meter, conductivity meter, titration, UV-Visible spectrometry, fluoride ion selective electrode and microwave plasmaatomic emission spectrometry, respectively. The mean physicochemical concentration of TDS, total alkalinity, total hardness, $\mathrm{HCO}_{3}^{-}, \mathrm{SO}_{4}{ }^{2-}, \mathrm{NO}_{3}^{-}, \mathrm{NO}_{2}^{-}, \mathrm{F}^{-}, \mathrm{Cl}^{-}, \mathrm{Ca}^{2+}, \mathrm{Mg}^{2+}, \mathrm{Na}^{+}, \mathrm{K}^{+}, \mathrm{pH}$ and $\mathrm{EC}$ in bottled water samples were found in the range (4.67-139), (12-165), (4-97), (16.3-202), (0.05-3.84), (0.02-0.84), (0.08-0.28), (0.03-1.26), $(4.28-20.8),(0.19-8.9),(0.02-2.5),(1.8-24.5),(0.14-8.08 \mathrm{mg} / \mathrm{L}),(6.43-7.69)$ and $(9.8-289 \mu \mathrm{s} / \mathrm{cm})$, respectively. The drinking water quality index (WQI) was calculated based on 15 important quality parameters and the results were found in the range 3.85-49.2. The mean concentrations of physicochemical parameters in almost all the bottled drinking water were below the permissible limit set by WHO and CES. Hence, all the tested bottled water samples are safe for drinking purpose.
\end{abstract}

KEY WORDS: Bottled water, Common cations, Common anions, Physicochemical parameters, Water quality index

\section{INTRODUCTION}

Water is one of the most important of all natural resources known on the earth. It is mainly used for drinking purposes which come from the surface and underground water sources [1]. $97 \%$ water exists in the oceans which are not suitable for drinking purpose and $3 \%$ is fresh water. Of the $3 \%$ fresh water $2.97 \%$ is comprised of glaciers and ice caps and remaining little portion of $0.3 \%$ are available as a surface and groundwater for human use [2]. A high quality water is required for drinking purposes for better health [3]. Freshwater is already a limiting resource in many parts of the world. In the next century, it will become even more limiting due to increased population, urbanization and climate changes. The safety of drinking water might be affected by various contaminants which includes chemical, physical and microbiological contaminants which can cause serious health problems to human [4]. Moreover, human beings depend on water for almost every developmental activity. Because of its importance, the pattern of human settlement throughout the history has often been determined by its availability [5].

Most of the diseases in developing countries are caused by the consumption of contaminated water. The people living in developing countries lack access to clean water due to environmental pollution [6]. The safety of drinking water is affected by various contamination of drinking water with chemical, microbiological and anthropogenic activities [7]. The chemical contaminants in potable water include: some heavy metals, non-metals, disinfection byproducts, nitrate, nitrite, pesticides, and sulfate [8]. In most urban-rural communities in the developing countries especially the Sub-Sahara Africa, surface waters (rivers, streams, and lakes

*Corresponding author. E-mail: fbeshah@yahoo.com

This work is licensed under the Creative Commons Attribution 4.0 International License 
among others) have been the most available sources of water used for domestic purposes. The water from these sources is contaminated with domestic, agricultural, and industrial wastes and likely to cause water-related diseases. Impaired surface water quality always result in an unhealthy socio-economic environment [9]. The levels of chemicals in drinking water are sometimes high enough to cause acute health effects. Polluted drinking water causes many diseases as diarrhea, vomiting, gastroenteritis, dysentery, kidney problems [10].

Water quality parameters are the physical, chemical, and biological characteristics of water in association to the set of standards $[1,11]$. Safe water is to say that drinking water need to be free from pathogenic organisms, toxic substances, an overdose of minerals and organic materials as well as it should be pleasant (free from color, turbidity, odor and taste) [1, 12]. Water quality parameters provide important information about the health of a water body. Besides, these parameters are used to find out the quality of water for drinking purpose [2]. The quality of water is the degree of its potability and is determined by the level of physicochemical, microbial and heavy metals (which include suspended and dissolved substances in the water, the degree of alkalinity $(\mathrm{pH})$, temperature, appearance in term of color, taste, odor and the presence of non desirable microorganisms). Water for domestic purposes should therefore be free from these substances in order to prevent waterborne diseases [13]. World Health Organization (WHO) publishes guidelines for drinking water quality $[14,15]$ which many countries use as the basis to establish their own national standards. The guidelines represent a scientific assessment of the risks to health from biological and chemical constituents of drinking water.

The bottled water first began in 1970, and with the promotion of this product bottled water market has grown, and by late 1990 multiplied by three times the soft drinks market. Water consumed by a human comes in various forms and from the various sources, bottled water is one of that forms [16]. Recently it has been increasing dramatically due to the ever increasing contamination of water resources. Bottled water consumption has been growing steadily worldwide during the last three decades and is regarded as fastest growing and most dynamic sector of all the foods and beverage industries. Consumption of bottled water is a proper choice in the world when no safe water is available or water treatment is difficult, but the safety of bottled water is important and it is necessary to monitor toxic and trace metal contaminants $[17,18]$. In order to protect health, people turn to consume bottled water and spend a lot of money to buy bottled water and drinking with the assumption that the bottled water is clean and safe than boiled water. The non-arrival of useful water for consumers, presence of odors and unpleasant taste in the water supplied by municipal, believe of consumers on the impact of medical and therapeutic bottled water gives a sense of height of the social level in addition to the promotion of media for the consumers [16].

Bottled water delivery service is an important part of the bottled water industry. For homes and offices, it is a convenient way to receive cost-effective; high quality drinking water on a regular basis. Studies have shown that use of purified water in the workplace increases productivity and improve the overall health of the workforce [19]. In the metropolitan cities, like Addis Ababa (Ethiopia), with large population size and the diplomatic headquarters of Africa enhances the commercialization and profitability of water as a product in the national and international market for Ethiopian bottled water manufacturers [18].

Several studies have been done on assessment of quality of bottled waters in the different cities in the world. These include determination of heavy metal profile in bottled water samples obtained from various markets in Lagos, Nigeria [8], classification and evaluation of commercial bottled drinking waters in Saudi Arabia [9], application of water quality index for assessment water quality in some bottled water in Erbil City, Kurdistan Region, Iraq [20], chemical assessment of bottled drinking waters by IC, GC, and ICP-MS [21], physical, chemical and microbial analysis of bottled drinking water [22], chemical water quality of bottled drinking water brands marketed in Mwanza City, Tanzania [23] and comparative study between bottled mineral and tap water in Italy [24]. 
Water quality index (WQI) is a very useful and efficient method for assessing the suitability of drinking water; it is also a very useful arithmetical tool used to transform large number of water quality data into a single cumulatively derived number and for communicating the information on the overall quality of water to the concerned citizens and policymakers [13, 25]. It, thus, becomes an important parameter for the assessment and management of water quality (both surface and groundwater). WQI reflects the composite influence of different water quality parameters and is calculated from the point of view of the suitability of both surface and groundwater for human consumption [20].

Several studies have been reported on the determination of water quality index of different water bodies in different countries. Some of these studies are determination of water quality index and suitability of urban river for municipal water supply in Lagos, Nigeria [13], determinations of water quality index and suitability of an urbawater body in Shimago Town, Karnataka, India [26], water quality assessment in terms of water quality index [27, 28], mathematical computation of water quality index of Vea Dam in Upper East Region of Ghana [29], assessment of water quality index of Robertson Lake Jabalpur (India) and use of test result in remote sensing application [30], water quality index assessment of Koudiat Medouar Reservoir, Northeast Algeria using weighted arithmetic index method [31], and water quality index for assessment of water samples of different zones in Chandrapur City (India) [32].

In developing countries, including Ethiopia, the drinking water quality is continuously being contaminated and become hazardous for human use due to high growth of population, expansion of industries, disposal of wastewater and chemical effluents into canals and other water sources [2]. In addition to water contamination by pathogenic microbes, which is common in Ethiopia, chemical pollution is rising with industrialization and with the widespread use of agricultural chemicals [33].

Some studies have been reported on the mineral composition of lake water, river water, and irrigation waters in Ethiopia [11, 34, 35]. Physicochemical analysis of drinking water has also been studied to assess the quality of drinking water in different cities and regions of Ethiopia [7, $33,36,37]$. A few studies have been conducted on the quality of bottled water in Ethiopia. These include the levels of common ions in bottled mineral waters consumed in Addis Ababa, Ethiopia [38] and the assessment of chemical quality of major brands of bottled water marketed in Gondar Town, Ethiopia [18]. However, water quality index has not been determined in any of the water bodies including river water, lake water, irrigation water, drinking water and bottled water in Ethiopia.

Recently consumption of bottled water has been increasing in every region of Ethiopia. But, the quality of bottled water used for human consumption is not subjected to any stringent quality control measures in Ethiopia. Therefore, the present study was carried out to assess the water quality index of bottled water marketed in Addis Ababa, Ethiopia, using measurements of major physiochemical parameters.

The main objective of this study was to determine water quality parameters and calculate the water quality index of bottled water marketed in Addis Ababa, Ethiopia and to compare with the values set by WHO. The specific objectives of the study were: (1) to determine (i) common cations $\left(\mathrm{Na}^{+}, \mathrm{K}^{+}, \mathrm{Ca}^{2+}, \mathrm{Mg}^{2+}\right)$ and anions $\left(\mathrm{F}^{-}, \mathrm{Cl}^{-}, \mathrm{SO}_{4}{ }^{2-}, \mathrm{NO}_{3}^{-}, \mathrm{NO}_{2}^{-}, \mathrm{HCO}_{3}\right)$ of bottled water and (ii) TDS, EC, hardness, $\mathrm{pH}$, and alkalinity of bottled water; (2) to compare (i) the levels of common ions in bottled water marketed in Addis Ababa with WHO and CES guidelines for drinking water, (ii) the measured values of physiochemical parameters with the labeled values and (iii) the physicochemical parameters of different brands of bottled water and (3) to calculate the water quality index of bottled drinking water in Addis Ababa to assess the quality of water as excellent, good, poor, very poor or unsuitable for drinking. 


\section{EXPERIMENTAL}

\section{Chemicals}

Analytical reagent grade sodium hydroxide, concentrated hydrochloric acid, concentrated sulfuric acid, anhydrous sodium sulfate, sulfanilamide, $\mathrm{N}$-(1-naphthyl) ethylene diamine dihydro chloride, potassium chromate, sodium salicylate, nitric acid (69-72\%), potassium sodium tartarate, diazotized sulfanilamide, silver nitrate, calcium carbonate, magnesium carbonate, sodium chloride, ethylene diamine tetra acetic acid (EDTA), glacial acetic acid, sodium fluoride, Eriochrome black T (EBT), bromocresol green (Sigma Aldrich, Germany), ethanol (99.99\%, Fisher Scientific, UK), phenolphthalein (Scharlau, European Union), glycerol solution, ammonium chloride, magnesium sulfate, methyl orange (Scharlau, European Union) were used in this study. All the chemicals and reagents whose production companies are not listed were supplied by Sigma Aldrich, Germany.

\section{Instruments}

The instruments used in this study includes: UV-Visible Spectrophotometer (Spectra max plus 385, UK), Microwave Plasma-Atomic Emission Spectrophotometer (Agilent Technologies, 4200 USA); Hotplate; Kjeldahl apparatus (Gallenhamp, USA), drying oven (Binder, Germany), pH meter (Model CP-505, Zabrze ul, Poland), conductivity meter (Orion Model 145, USA), and fluoride ion selective electrode (Orion, model 940 expandable ion analyzer, USA).

\section{Sampling area}

The present study was carried out at Addis Ababa, which is a capital city of Ethiopia. The population of the city is currently estimated to be 4.6 million [39]. It is located in the geographical coordinate $3^{0}-15^{0} \mathrm{~N}$ and $33^{0}-48^{0} \mathrm{E}$ with an estimated area of $1,104,300 \mathrm{sq} \mathrm{km}$ [40]. Besides, Addis Ababa is a city of political and economic significance being a base for African Union and many other international organizations. The inhabitants are receiving drinking water from Dire Dam situated at the air distance of $20 \mathrm{~km}$, Legedadi Dam at the air distance of 19.50 $\mathrm{km}$, Gefersa Dam situated at the air distance of $18.20 \mathrm{~km}$ apart from Addis Ababa Water Supply Administration (AAWSA) office and Akaki water supply system and spring waters and boreholes around the border of the city mainly Akaki sub-city [41]. In addition to tap water supply, the city has an easy access to different brands of bottled water, which are mainly used for drinking purpose.

Water samples collection

Twenty different brands of bottled waters $\left(\mathrm{Bw}_{1}, \mathrm{Bw}_{2}, \mathrm{Bw}_{3}, \mathrm{Bw}_{4}, \mathrm{Bw}_{5}, \mathrm{Bw}_{6}, \mathrm{Bw}_{7} \mathrm{Bw}_{8}, \mathrm{Bw}_{9}\right.$, $\mathrm{Bw}_{10}, \mathrm{Bw}_{11}, \mathrm{Bw}_{12}, \mathrm{Bw}_{13}, \mathrm{Bw}_{14}, \mathrm{Bw}_{15}, \mathrm{Bw}_{16} \mathrm{Bw}_{17}, \mathrm{Bw}_{18}, \mathrm{Bw}_{19}$, and $\mathrm{Bw}_{20}$ ) were selected for the present study. Each of the drinking bottled water was randomly purchased from shops and supermarkets from different locations in Addis Ababa during January and February 2018. Once all the samples were brought to laboratory, it was kept at $4{ }^{\circ} \mathrm{C}$ in the refrigerator with their original sale containers until analysis was carried out. The holding capacities of bottled water containers were $0.5,1$ and $2 \mathrm{~L}$. For each brand of bottled water, three identical samples of bottled water were mixed to make a bulk sample. Furthermore, the sampled water was classified as natural spring, natural mineral and purified water. The brands of bottled water and sources of bottled water used in this study are described in Table 1.

Analytical procedures for the determination of physicochemical analysis

Total dissolved solids and electrical conductivity. Total dissolved solids (TDS) and electrical conductivity (EC) measurements were made using Thermo Orion Model 145, USA. The 
instrument was calibrated with distilled water. An aliquot of $30 \mathrm{~mL}$ water sample was transferred to a $50 \mathrm{~mL}$ plastic beaker and put on the plate having a magnetic stirrer, and the instrument sensor was inserted to the beaker to measure the parameters. During the measurement the solutions were stirred constantly in order to homogenize and the measurement was performed in triplicate.

Table 1. Types and sources of bottled mineral water used in the present study.

\begin{tabular}{|l|l|l|l|}
\hline No. & Bottled water brand & Water type & Source of water \\
\hline 1 & $\mathrm{Bw}_{1}$ & Natural spring water & Entoto mountain, Sululta \\
\hline 2 & $\mathrm{Bw}_{2}$ & Springs water & Ayer Tena, outskirts of Addis Ababa \\
\hline 3 & $\mathrm{Bw}_{3}$ & Natural spring water & Burayu \\
\hline 4 & $\mathrm{Bw}_{4}$ & Natural spring water & Debre Birhan \\
\hline 5 & $\mathrm{Bw}_{5}$ & Natural mineral water & Highlands of Sululta \\
\hline 6 & $\mathrm{Bw}_{6}$ & Natural spring water & Holrta Genet \\
\hline 7 & $\mathrm{Bw}_{7}$ & Natural purified water & Entoto mountain, Sululta \\
\hline 8 & $\mathrm{Bw}_{8}$ & Purified spring water & Menagesha mountain \\
\hline 9 & $\mathrm{Bw}_{9}$ & Natural mineral water & Burayu, Oromia region \\
\hline 10 & $\mathrm{Bw}_{10}$ & Natural spring water & Gurage area \\
\hline 11 & $\mathrm{Bw}_{11}$ & Natural spring water & Gurage mountain \\
\hline 12 & $\mathrm{Bw}_{12}$ & Pure mineral water & Gefersamona, Tatek \\
\hline 13 & $\mathrm{Bw}_{13}$ & Purified natural water & Sululita, Oromia \\
\hline 14 & $\mathrm{Bw}_{14}$ & Purified natural water & Alemgena, Oromia \\
\hline 15 & $\mathrm{Bw}_{15}$ & Natural mineral water & Koce mountain, Sebeta \\
\hline 16 & $\mathrm{Bw}_{16}$ & Natural purified water & Sebeta, Oromia region \\
\hline 17 & $\mathrm{Bw}_{17}$ & Natural mineral water & Alemgena, Oromia \\
\hline 18 & $\mathrm{Bw}_{18}$ & Natural spring water & Mugo Highlands \\
\hline 19 & $\mathrm{Bw}_{19}$ & Natural purified water & Chained mountain of Gurage region \\
\hline 20 & $\mathrm{Bw}_{20}$ & Natural purified water & Wechecha mountain \\
\hline
\end{tabular}

Note: Bw is bottled water; number 1-20 indicates sample number of bottled water.

$p H$. The $\mathrm{pH}$ values of the bottled water samples were measured using a $\mathrm{pH}$ meter (Model CP $505)$ in triplicate. The $\mathrm{pH}$ electrode was rinsed with deionized water and calibrated with $\mathrm{pH}$ $4.00,7.00$ and 10.00, standard buffer solutions. The $\mathrm{pH}$ electrode was rinsed with deionized water to avoid contamination of the buffers. The $\mathrm{pH}$ values of the bottled water samples were measured by inserting the electrode in $50 \mathrm{~mL}$ of the bottled water sample in a beaker using the $\mathrm{pH}$ meter in triplicate.

Total alkalinity. The alkalinity of the sample was determined by titrating with standard sulfuric acid $(0.02 \mathrm{M})$ using phenolphthalein and bromocresol indicators. $25 \mathrm{~mL}$ of bottled sample was transferred into conical flask and phenolphthalein and bromocresol indicators were added to the flask. Finally, the solution was titrated with $\mathrm{H}_{2} \mathrm{SO}_{4}$ [42]. The concentration of total alkalinity was calculated by useing equation 1 .

Total alkalinity as $\mathrm{CaCO}_{3}=\frac{\text { Volume of sulfuric acid } \times \text { Molarity of sulfuric acid } \times 50 \times 1000}{\text { Volume of sample }}$

Bicarbonate. The same procedure as alkalinity was used in measurement of bicarbonates as recommended by [42], except the one conversion factor change in the formula which is 61 instead of 50 .

Bicarbonate $=\frac{\text { Volume of sulfuric acid } \times \text { Molarity of sulfuric acid } \times 61 \times 1000}{\text { Volume of sample }}$ 
Total hardness. The total hardness of the water was determined by complexometric titration using EBT indicator and ammonium-ammonium chloride buffer solution. The buffer solution was prepared by weight $1.17 \mathrm{~g}$ of EDTA, $16.9 \mathrm{~g}$ of ammonium chloride, $780 \mathrm{mg}$ of magnesium sulfate and $143 \mathrm{~mL}$ of ammonium hydroxide solution and trnasfer to the beaker which contains $500 \mathrm{~mL}$ distilled water. The solution was stirred until all the solids were dissolved, and its $\mathrm{pH}$ was found to be 10. Before the titration, the burette was rinsed with EDTA solution and filled with $0.02 \mathrm{M}$ EDTA standard solutions. An aliquot of $25 \mathrm{~mL}$ sample water was transferred to a conical flask and then 2 drops of EBT indicator and $1 \mathrm{~mL}$ buffer solution were added the beaker. Finally the solution was titrated against to EDTA solution which was filled in the burette. The same procedure was used for three blank samples. The total hardness of the water sample was calculated by using the equation 3 as calcium carbonate $(\mathrm{mg} / \mathrm{L})$ [43].

Total hardness as $\mathrm{CaCO}_{3}=\frac{\text { Volume EDTA } \times \text { Molarity EDTA } \times 50 \times 1000}{\text { Volume of sample }}$

Chloride. The concentration of chloride was determined by titration. $1 \mathrm{~mL}$ of potassium chromate indicator and $25 \mathrm{~mL}$ sample water was added in the beaker, and the solution was titrated with $(0.1 \mathrm{M})$ silver nitrate. The solution was stirred by magnetic stirrer while titration was carried out. The performance of the method was checked by a standard solution of sodium chloride. The same analytical procedures were used for the determination of chloride in three blank samples. The chloride concentration was calculated by this formula [44].

Chloride $=\frac{(\text { Volume siliver nitrate }- \text { blank }) \times \text { Normality siliver nitrate } \times \text { MW of chloride } \times 1000}{\text { Volume of sample }}$

$\mathrm{MW}=$ molecular weight.

Fluoride. To determine the levels of fluoride in the sampled water, total ionic strength adjustment buffer (TISAB) was prepared by dissolving $58 \mathrm{~g}$ sodium chloride, $2 \mathrm{~g}$ EDTA, $7 \mathrm{~g}$ trisodium acetate and $57 \mathrm{~mL}$ glacial acetic acid in $500 \mathrm{~mL}$ deionized water. Finally, the $\mathrm{pH}$ was adjusted to 5.3 by using $5 \mathrm{M}$ sodium hydroxide solution, and made up to one liter with deionized water. TISAB was used to obtain a $\mathrm{pH}$ of 5.2-5.4, which is the optimum $\mathrm{pH}$ range for fluoride determination. $10 \mathrm{~mL}$ of TISAB and $10 \mathrm{~mL}$ of calibration solution were mixed in a beaker for measurement of $\mathrm{F}^{-}$in the solution. Similar amount of TISAB was used for instrument calibration. $0.5,1,5,10$ and $20 \mathrm{mg} / \mathrm{L}$ series standard solution of fluoride were prepared for the instrument calibration. The slope of the calibration curve found to be $58.6 \mathrm{mV}$ which is within the acceptable range $(54-60 \mathrm{mV})$. Similar procedure was used for the measurement of fluoride concentrations in sample water. Thus, equal volumes $10 \mathrm{~mL}$ of water samples and $10 \mathrm{~mL}$ of TISAB were mixed in a $50 \mathrm{~mL}$ plastic beaker and the mixture were stirred thoroughly using a magnetic stirrer while measuring. The concentration of fluoride was read directly from fluoride potentiometer and triplicate measurements were made.

Sulfate. The concentration of sulfate in the sample was determined by spectrophotometric method. A stock standard sulfate solution was prepared by dissolving $147.9 \mathrm{mg}$ anhydrous sodium sulfate $\left(\mathrm{Na}_{2} \mathrm{SO}_{4}\right)$ in $1000 \mathrm{~mL}$ of distilled water. Conditioning reagent was prepared by mixing of $50 \mathrm{~mL}$ glycerol solution, $30 \mathrm{~mL}$ concentrated hydrochloric acid ( $\mathrm{HCl}), 100 \mathrm{~mL} \mathrm{95 \%}$ ethanol, $300 \mathrm{~mL}$ distilled water and $75 \mathrm{~g}$ sodium chloride $(\mathrm{NaCl}) .100 \mathrm{~mL}$ of the sample water and $5 \mathrm{~mL}$ of conditioning reagent were transferred to $250 \mathrm{~mL}$ flask, and then a spoonful $(10 \mathrm{~g})$ of barium chloride crystals was added, mixed and placed on a magnetic stirrer and stirred at a constant speed exactly for one minute. Finally, $1 \mathrm{~mL}$ amount of the solutions was poured on absorption cell of the photometer, and turbidity of the solution was measured at 30 second intervals for four minutes at $420 \mathrm{~nm}$. The same analytical procedures were used for the determination of sulfate ions in three blank samples [42]. 
Nitrite. The concentration of nitrite was determined by a colorimetric method [42]. $25 \mathrm{~mL}$ bottled water sample, $1 \mathrm{~mL}$ of nitrite and $1 \mathrm{~mL}$ of sulfanilamide solution were added to a 250 $\mathrm{mL}$ conical flask and allowed for $5 \mathrm{~min} .1 \mathrm{~mL}$ of $\mathrm{N}$-(1-naphthyl)ethylenediamine solution was added and mixed well. After $10 \mathrm{~min}$ absorbance was measured using UV-Visible spectrophotometer at a wavelength of $543 \mathrm{~nm}$. The same analytical procedure was used for the determination of nitrite in three blank samples. The concentration of $\mathrm{NO}_{2}{ }^{-}$was calculated from the standard calibration curve.

Nitrate. The concentration of nitrate was determined by sodium-salicylate method [42]. First, 10 $\mathrm{mL}$ of bottled water sample and $1 \mathrm{~mL}$ of sodium-salicylate were transferred into a $250 \mathrm{~mL}$ conical flask and kept it in an oven at a temperature of $95^{\circ} \mathrm{C}$. The residue was dissolved in $1 \mathrm{~mL}$ of $\mathrm{H}_{2} \mathrm{SO}_{4}$, swirling the conical flask carefully while it is still warm. Secondly, $50 \mathrm{~mL}$ of distilled water and $7 \mathrm{~mL}$ of $\mathrm{NaOH}$ tartrate solution were mixed and diluted it to $100 \mathrm{~mL}$ by distilled water. The analysis is based on the reaction of the nitrate with sodium salicylate in a sulfuric acid medium, which forms a yellow colored salt of nitro salicylic acid. The intensity of color is directly proportional to the nitrate concentration and the absorbance was measured using UVVisible spectrophotometer at a wavelength of $410 \mathrm{~nm}$. The same analytical procedures were employed for the determination of nitrate ion in three blank samples. Finally, the concentration of $\mathrm{NO}_{3}{ }^{-}$was calculated from the standard calibration curve.

\section{Analytical procedures for the determination of common cations}

For the determination of metal ions in the water sample, $50 \mathrm{~mL}$ of each water sample was acidified with $5 \mathrm{~mL}$ of nitric acid (69-72\%), and the mixture was digested in a fume cupboard for one hour at $100{ }^{\circ} \mathrm{C}$ until a clear solution was seen. After cooling, the mixture was filtered and the filtrate was transferred to a $50 \mathrm{~mL}$ volumetric flask and diluted with deionized water until the mark. This digestion was carried out in triplicate manner. Finally, calcium, magnesium, potassium and sodium were determined using microwave plasma-atomic emission spectrophotometer (MP-AES). $0,5,10,15,20 \mathrm{mg} / \mathrm{L}$ standard solution of $\mathrm{Mg}^{2+}, \mathrm{Ca}^{2+}, \mathrm{Na}^{+}$were prepared from the stock solution, similarly $0,5,10,20,40 \mathrm{mg} / \mathrm{L}$ of $\mathrm{K}^{+}$standard solution was prepared from potassium stock solution (calibration standard, Buck Scientific, USA), by using $2 \% \mathrm{HNO}_{3}$. Using these standard solutions, the calibration curves for each metal were obtained. The correlation coefficients of the graphs were found to be higher than 0.999 for all the analytes. Immediately after calibration, the sample solutions were aspirated into the MP-AES instrument and the metal concentrations were recorded. Three replicate determinations were carried out for each sample. The same analytical procedures were employed for the determination of the metals in twelve blank samples.

\section{Assessment of water quality index (WQI) of bottled water samples}

The water quality index was calculated by using the standards procedure of drinking water quality guidelines set by the WHO. The weight arithmetic method was used for calculation of water quality index of the water system [45]. The WQI was calculated for the 15 physicochemical parameters (EC, TDS, $\mathrm{pH}$, total alkalinity, total hardness, fluoride, chloride, nitrate, nitrite, sulfate, $\mathrm{Ca}^{+2}, \mathrm{Mg}^{+2}, \mathrm{~K}^{+}$, and $\mathrm{Na}^{+}$). The computed WQI values are classified into five categories as: excellent, good, poor, very poor and unstable water quality [26-31] (Table 2). Thus, water quality parameters and quality rating (qi) corresponding to $\mathrm{n}^{\text {th }}$ term parameter is a number reflecting the relative value of this parameter in the polluted water with respect to its standard permissible limit value [13, 20, 29, 31, 32].

qi $=\frac{100(\mathrm{Vn}-\mathrm{Vi})}{(\mathrm{Vs}-\mathrm{Vi})}$ 
where, $\mathrm{Vs}=$ standard value; $\mathrm{Vi}=$ ideal value. In most cases $\mathrm{Vi}=0$ except in certain parameters like $\mathrm{pH}$, the calculation of quality rating for $\mathrm{pH}$ (Vi was not zero). $\mathrm{q} \mathrm{pH}=100(\mathrm{~V} \mathrm{pH}-7.0)$ / (8.5-7.0).

Calculation of unit weight. The unit weight (Wi) of various water quality parameters is inversely proportional to the recommended standards for the corresponding parameters.

$\mathrm{Wi}=\frac{1}{S i}$

where, $\mathrm{Wi}=$ unit weight for the $\mathrm{n}^{\text {th }}$ parameter and $\mathrm{Si}=$ standards permissible value of $\mathrm{n}^{\text {th }}$ parameter. Water quality index (WQI) is calculated using equation 7:

$\mathrm{WQI}=\frac{\Sigma \mathrm{qi} \mathrm{Wi}}{\Sigma \mathrm{Wi}}$

Table 2. Water quality index levels, quality status and grading.

\begin{tabular}{|c|c|c|}
\hline Water quality index level & Water quality status & Grading quality \\
\hline $0-25$ & Excellent water quality & A \\
\hline $26-50$ & Good water quality & B \\
\hline $51-75$ & Poor water quality & D \\
\hline $76-100$ & Very poor water quality & E \\
\hline$>100$ & Unsuitable for drinking & \\
\hline
\end{tabular}

\section{Statistical analysis}

The relationships (correlation) among physicochemical parameters were assessed by Pearson correlation methods using statistical software (SPSS Version 21). Besides, the graphical expression was done using Microsoft excel 7 in addition to arrangements of different data sets.

\section{RESULTS AND DISCUSSION}

Accuracy and precision of results

Accuracy and precision are probably the most often quoted terms to express the extent of errors in a given analytical results. Analytical results must be evaluated to decide on the best values to report and attempt to establish the probable limits of errors of the values. The analyst is thus concerned with the question of precision (repeatability of results), that is the agreement between the set of results. It can be determined by standard deviation, variance, and coefficient of variance, and mean of measurements. In this study, the standard deviation and mean of the results of triplicate measurements for all the 15 parameters from each sample $(n=20)$ were used to know the precision of the method.

\section{Method validation for metal analysis}

The efficiency of the optimized procedure is checked by various methods. These are certified standard reference solution analyzing and spiking sample with a known concentration of the analyte. In this work, method validation was established by spiking experiments (recovery test). The spiked samples were prepared by adding, $0.68,0.43,0.22$ and $0.79 \mathrm{mg} / \mathrm{L}$ standard metal solution to $50 \mathrm{~mL}$ of bottled water. The spiked and unspiked water samples were digested and analyzed in similar manner. The percentage recovery of the analyte was calculated by using equation 8. 
Recovery $\%=\frac{\text { Conc. of metal in the spiked sample }- \text { Conc. of metal unspiked samples }}{\text { Conc. of metal added for spiking }} \times 100$

The results of percentage recoveries for the studied metals in bottled water samples were within the acceptable range $94.1-103 \%$. Therefore, this verifies that the optimized digestion procedure and the measurement procedure were valid for the analysis of bottled water.

\section{Levels of physicochemical parameters}

Total dissolved solid (TDS). The concentration of total dissolved solid in the studied bottled water samples ranged 4.67-139 $\mathrm{mg} / \mathrm{L}$. The WHO [15] recommended TDS value below 500 $\mathrm{mg} / \mathrm{L}$ as acceptable for drinking water, while the Ethiopian Standard extends the limit to 1000 $\mathrm{mg} / \mathrm{L}$ [46]. When compared with other bottled waters investigated, the concentration of total dissolved solid was higher in $\mathrm{Bw}_{15}, \mathrm{Bw}_{4}, \mathrm{Bw}_{19}, \mathrm{Bw}_{9}$, and $\mathrm{Bw}_{17}$ bottled waters than the other brand types (Table 3). Moreover, the concentration of total dissolved solid reported on the label of each of the bottled water particularly in $\mathrm{Bw}_{18}, \mathrm{Bw}_{14}, \mathrm{Bw}_{7}, \mathrm{Bw}_{5}, \mathrm{Bw}_{1}, \mathrm{Bw}_{12}, \mathrm{Bw}_{17}$ and $\mathrm{Bw}_{4} \mathrm{was}$ much higher than the finding of the present study. The present study was in contrast with the finding of Jafari et al. [47] who reported the highest value of TDS (326-461 mg/L) while it remains in a range between $4.67-139 \mathrm{mg} / \mathrm{L}$ in the present study. In addition, Momani [21] also reported a higher value of TDS in a bottled water with a minimum value of $112 \mathrm{mg} / \mathrm{L}$, whereas the lowest concentration in the present study was $4.67 \mathrm{mg} / \mathrm{L}$. All the bottled water samples investigated in this study are safe to drink from the total dissolved solid point of view.

Table 3. The value of physicochemical parameters in the investigated bottled water (mean $\pm \mathrm{SD}$ ).

\begin{tabular}{|c|c|c|c|c|c|}
\hline Sample & TDS $(\mathrm{mg} / \mathrm{L})$ & $\mathrm{pH}$ & $\mathrm{EC}(\mu \mathrm{s} / \mathrm{cm})$ & $\mathrm{TH}(\mathrm{mg} / \mathrm{L})$ & $\mathrm{TA}(\mathrm{mg} / \mathrm{L})$ \\
\hline $\mathrm{Bw}_{1}$ & $87.3 \pm 0.58$ & $7.69 \pm 0.03$ & $186 \pm 0.90$ & $46.0 \pm 2.00$ & $93.3 \pm 2.31$ \\
\hline $\mathrm{Bw}_{2}$ & $19.0 \pm 0.10$ & $6.97 \pm 0.02$ & $41.1 \pm 0.85$ & $14.7 \pm 2.31$ & $25.3 \pm 2.31$ \\
\hline $\mathrm{Bw}_{3}$ & $66.3 \pm 1.15$ & $7.03 \pm 0.25$ & $139 \pm 1.27$ & $20.0 \pm 2.00$ & $78.7 \pm 2.31$ \\
\hline $\mathrm{Bw}_{4}$ & $123 \pm 0.58$ & $7.11 \pm 0.01$ & $256 \pm 2.65$ & $97.3 \pm 2.31$ & $82.7 \pm 4.62$ \\
\hline $\mathrm{Bw}_{5}$ & $76.3 \pm 0.58$ & $7.22 \pm 0.11$ & $161 \pm 0.47$ & $54.7 \pm 2.31$ & $84.0 \pm 4.00$ \\
\hline $\mathrm{Bw}_{6}$ & $28.7 \pm 0.58$ & $7.37 \pm 0.06$ & $60.6 \pm 0.70$ & $9.33 \pm 2.31$ & $36.0 \pm 1.00$ \\
\hline $\mathrm{Bw}_{7}$ & $66.0 \pm 0.60$ & $7.35 \pm 0.05$ & $139 \pm 0.23$ & $60.0 \pm 2.00$ & $85.3 \pm 2.31$ \\
\hline $\mathrm{Bw}_{8}$ & $7.00 \pm 0.10$ & $7.20 \pm 0.09$ & $15.1 \pm 0.17$ & $8.00 \pm 0.20$ & $12.0 \pm 0.30$ \\
\hline $\mathrm{Bw}_{9}$ & $107 \pm 1.50$ & $7.48 \pm 0.08$ & $225 \pm 1.00$ & $96.0 \pm 1.00$ & $127 \pm 2.31$ \\
\hline $\mathrm{Bw}_{10}$ & $34.7 \pm 0.58$ & $7.30 \pm 0.27$ & $72.1 \pm 0.99$ & $24.0 \pm 0.40$ & $45.3 \pm 2.31$ \\
\hline $\mathrm{Bw}_{11}$ & $31.0 \pm 0.70$ & $6.94 \pm 0.04$ & $65.9 \pm 0.53$ & $26.7 \pm 1.15$ & $33.3 \pm 2.31$ \\
\hline $\mathrm{Bw}_{12}$ & $38.0 \pm 0.40$ & $7.04 \pm 0.07$ & $80.0 \pm 0.45$ & $32.0 \pm 0.60$ & $44.0 \pm 0.70$ \\
\hline $\mathrm{Bw}_{13}$ & $46.0 \pm 0.80$ & $7.60 \pm 0.05$ & $96.3 \pm 0.06$ & $16.0 \pm 0.20$ & $57.3 \pm 2.31$ \\
\hline $\mathrm{Bw}_{14}$ & $80.7 \pm 0.58$ & $7.36 \pm 0.47$ & $170 \pm 0.86$ & $42.7 \pm 2.31$ & $96.0 \pm 4.00$ \\
\hline $\mathrm{Bw}_{15}$ & $139 \pm 1.53$ & $7.29 \pm 0.02$ & $289 \pm 2.51$ & $44.0 \pm 4.00$ & $165 \pm 2.31$ \\
\hline $\mathrm{Bw}_{16}$ & $18.0 \pm 0.60$ & $6.43 \pm 0.15$ & $38.9 \pm 0.32$ & $12.0 \pm 0.10$ & $27.3 \pm 4.16$ \\
\hline $\mathrm{Bw}_{17}$ & $102 \pm 1.00$ & $7.56 \pm 0.32$ & $215 \pm 2.08$ & $74.7 \pm 2.31$ & $123 \pm 2.31$ \\
\hline $\mathrm{Bw}_{18}$ & $37.3 \pm 0.58$ & $7.03 \pm 0.12$ & $78.7 \pm 0.78$ & $17.3 \pm 5.03$ & $41.3 \pm 2.31$ \\
\hline $\mathrm{Bw}_{19}$ & $127 \pm 1.53$ & $7.55 \pm 0.05$ & $266 \pm 3.00$ & $46.7 \pm 2.31$ & $143 \pm 2.31$ \\
\hline $\mathrm{Bw}_{20}$ & $4.67 \pm 0.58$ & $6.52 \pm 0.21$ & $9.87 \pm 0.90$ & $4.00 \pm 0.05$ & $13.3 \pm 2.31$ \\
\hline
\end{tabular}

Electrical conductivity (EC). The highest and the lowest value of electrical conductivity recorded in the present study were 9.8 and $289 \mu \mathrm{s} / \mathrm{cm}$ in $\mathrm{Bw}_{20}$ and $\mathrm{Bw}_{15}$ bottled water, respectively (Table 3). According to WHO [15] the maximum permissible limit of electrical conductivity in drinking water is $1000 \mu \mathrm{s} / \mathrm{cm}$. The electrical conductivity found in the present study is much lower as compared with the permissible limit set by WHO [15]. Jafari et al. [47] have reported electrical conductivity values ranged from 706 to $976 \mu \mathrm{s} / \mathrm{cm}$ in drinking water which are higher than the finding of the present study. However, the finding of the present study 
is a similar with the finding of Reda [36] who reported the electrical conductivity value of drinking water ranged between 210 to $231 \mu \mathrm{s} / \mathrm{cm}$ in Arba Minch. The investigated parameters of all the bottled mineral waters lie in an acceptable limit for drinking purpose as recommended by WHO [14].

$p H$. The $\mathrm{pH}$ of the 20 brands of bottled water ranged 6.43-7.69 where the lowest and the highest value was recorded for $\mathrm{Bw}_{16}$ and $\mathrm{Bw}_{1}$ bottled mineral water, respectively (Table 3 ). According to the recommendation of WHO [15] and CES [46], the permissible range of $\mathrm{pH}$ in a drinking water should be in the range 6.5-8.5. In this regard, the $\mathrm{pH}$ value of $\mathrm{Bw}_{16}$ bottled mineral water is lower than from the minimum range drinking water set by WHO [15] and CES [46]. All the remaining 19 bottled mineral water have a $\mathrm{pH}$ value lies within the range recommended by WHO [15]. The finding of the present study is in agreement with the finding by Momani [21]. Similarly in Italy, Sasikaran et al. [22] have reported the $\mathrm{pH}$ value of bottled water above the middle of the permissible limit. At $\mathrm{pH}$ values less than 6.5 , water is corrosive and dissolves plumbing components. This is especially a concern when water contacts brass and copper piping where copper, zinc, and lead dissolve into the drinking water. Whereas $\mathrm{pH}$ values $\geq 8.5$ of drinking water can promote hardness scale, precipitation and make chlorine disinfectants more effective.

Total hardness. The total hardness value in bottled water samples were ranged from $4 \mathrm{mg} / \mathrm{L}$ to $97 \mathrm{mg} / \mathrm{L}$ as calcium carbonate in $\mathrm{Bw}_{20}$ and $\mathrm{Bw}_{4}$, respectively (Table 3). The values of total hardness in all of the bottled water lie in permissible limits for drinking water $(<500 \mathrm{mg} / \mathrm{L})$ set by WHO [14]. Although for all the bottled water samples the total hardness is below the recommendations of WHO [14], there is no labeled values on all the bottled water measured in this study (except $\mathrm{Bw}_{7}$ bottled water was $13.3 \mathrm{mg} / \mathrm{L}$ ). In this study, the concentration of total hardness in $\mathrm{Bw}_{7}$ bottled water was $60 \mathrm{mg} / \mathrm{L}$ as calcium carbonate which is higher than from the labeled values on it.

Total alkalinity. The mean concentration of total alkalinity ranged from 12 to $165 \mathrm{mg} / \mathrm{L}$ in $\mathrm{Bw}_{8}$ and $\mathrm{Bw}_{15}$, respectively (Table 3 ). The maximum concentration limit of total alkalinity described by WHO [15] and CES [46] is $200 \mathrm{mg} / \mathrm{L}$. In this study the value of total alkalinity in all the bottled drinking water was found below the permissible limit. The total alkalinity labeled at the bottled drinking water were 0.69, 7, 8.33, 85, $104 \mathrm{mg} / \mathrm{L}$ in $\mathrm{Bw}_{10}, \mathrm{Bw}_{16}, \mathrm{Bw}_{8}, \mathrm{Bw}_{19}, \mathrm{Bw}_{17}$, respectively, but other bottled water were not labeled the concentration of total alkalinity. The minimum value of total alkalinity in this study was recorded in the $\mathrm{Bw}_{8}$ bottled water which is higher than the label at bottled water. On the other hand, the maximum value of total alkalinity of this study was $165 \mathrm{mg} / \mathrm{L}$ in $\mathrm{Bw}_{15}$ bottled drinking water which is higher than the label at the $\mathrm{Bw}_{15}$ bottled water. The concentration of alkalinity reported by Reimann et al. [37] range from 15 to $1070 \mathrm{mg} / \mathrm{L}$ in drinking water in Ethiopian Rift Valley where the maximum of the range was higher than WHO permissible limit [15]. The reported result by Reda [36] range from 88.6$181 \mathrm{mg} / \mathrm{L}$ thus the maximum and minimum range is above the values found in this study.

Levels of common cations and anions in the water samples

Calcium. The mean calcium concentration was found in the range $0.19-8.9 \mathrm{mg} / \mathrm{L}$, and the results are summarized in Table 4. The highest concentration of calcium was found in $\mathrm{Bw}_{9}$ bottled water samples while the lowest values were found in $\mathrm{Bw}_{8}$. The mean calcium value found in $\mathrm{Bw}_{1}, \mathrm{Bw}_{3}$ and $\mathrm{Bw}_{4}$ are lower than to the values reported by Seda et al. [38]. All the bottled water samples are below WHO permissible limit $(200 \mathrm{mg} / \mathrm{L})$ that confirms all bottled water are safe to drink. According to study conducted by Mihayo and Mkoma [23], maximum and the minimum levels of calcium were $14 \mathrm{mg} / \mathrm{L}$ and $3.4 \mathrm{mg} / \mathrm{L}$, respectively, in which the concentration of calcium was higher than in the present study. Similarly, Mekonnen et al. [18] 
have reported the mean concentrations of calcium range from 3 to $28.3 \mathrm{mg} / \mathrm{L}$, this concentration of calcium is relatively higher than that found in the present study.

Table 4. The concentration of common cations $(\mathrm{mg} / \mathrm{L})$ in the bottled mineral waters investigated (mean \pm $\mathrm{SD})$.

\begin{tabular}{|l|l|l|l|l|}
\hline Sample & Calcium & Magnesium & Potassium & Sodium \\
\hline $\mathrm{Bw}_{1}$ & $4.30 \pm 0.41$ & $1.11 \pm 0.07$ & $1.93 \pm 0.29$ & $20.2 \pm 3.65$ \\
\hline $\mathrm{Bw}_{2}$ & $1.18 \pm 0.08$ & $0.42 \pm 0.04$ & $0.59 \pm 0.03$ & $1.80 \pm 0.10$ \\
\hline $\mathrm{Bw}_{3}$ & $1.54 \pm 0.37$ & $0.45 \pm 0.03$ & $2.14 \pm 0.23$ & $19.7 \pm 2.10$ \\
\hline $\mathrm{Bw}_{4}$ & $7.93 \pm 0.84$ & $2.30 \pm 0.19$ & $2.05 \pm 0.19$ & $7.39 \pm 0.53$ \\
\hline $\mathrm{Bw}_{5}$ & $4.65 \pm 0.63$ & $0.67 \pm 0.57$ & $0.46 \pm 0.20$ & $9.55 \pm 1.86$ \\
\hline $\mathrm{Bw}_{6}$ & $0.34 \pm 0.01$ & $0.55 \pm 0.41$ & $0.38 \pm 0.07$ & $9.51 \pm 0.54$ \\
\hline $\mathrm{Bw}_{7}$ & $3.40 \pm 0.13$ & $2.15 \pm 0.02$ & $1.11 \pm 0.01$ & $3.91 \pm 0.12$ \\
\hline $\mathrm{Bw}_{8}$ & $0.19 \pm 0.03$ & $0.02 \pm 0.01$ & $0.14 \pm 0.03$ & $4.20 \pm 0.91$ \\
\hline $\mathrm{Bw}_{9}$ & $8.09 \pm 0.37$ & $2.51 \pm 0.09$ & $1.28 \pm 0.16$ & $9.16 \pm 0.45$ \\
\hline $\mathrm{Bw}_{10}$ & $1.72 \pm 0.16$ & $0.56 \pm 0.05$ & $1.43 \pm 0.13$ & $4.68 \pm 0.48$ \\
\hline $\mathrm{Bw}_{11}$ & $1.85 \pm 0.13$ & $0.59 \pm 0.04$ & $1.99 \pm 0.10$ & $3.60 \pm 0.27$ \\
\hline $\mathrm{Bw}_{12}$ & $2.41 \pm 0.02$ & $0.78 \pm 0.06$ & $1.95 \pm 0.16$ & $3.74 \pm 0.37$ \\
\hline $\mathrm{Bw}_{13}$ & $0.76 \pm 0.06$ & $0.35 \pm 0.02$ & $0.29 \pm 0.03$ & $11.8 \pm 0.18$ \\
\hline $\mathrm{Bw}_{14}$ & $3.34 \pm 0.42$ & $1.01 \pm 0.10$ & $3.90 \pm 0.25$ & $13.2 \pm 1.03$ \\
\hline $\mathrm{Bw}_{15}$ & $2.49 \pm 0.51$ & $1.13 \pm 0.23$ & $1.51 \pm 0.28$ & $24.5 \pm 0.33$ \\
\hline $\mathrm{Bw}_{16}$ & $0.44 \pm 0.08$ & $0.10 \pm 0.03$ & $0.77 \pm 0.08$ & $7.28 \pm 0.57$ \\
\hline $\mathrm{Bw}_{17}$ & $6.14 \pm 0.27$ & $2.10 \pm 0.08$ & $2.10 \pm 0.04$ & $14.5 \pm 0.24$ \\
\hline $\mathrm{Bw}_{18}$ & $1.26 \pm 0.01$ & $0.56 \pm 0.02$ & $3.15 \pm 0.06$ & $6.87 \pm 0.23$ \\
\hline $\mathrm{Bw}_{19}$ & $2.03 \pm 1.97$ & $1.48 \pm 0.04$ & $8.08 \pm 0.23$ & $24.1 \pm 1.47$ \\
\hline $\mathrm{Bw}_{20}$ & $0.26 \pm 0.01$ & $0.02 \pm 0.01$ & $0.21 \pm 0.04$ & $2.45 \pm 0.01$ \\
\hline
\end{tabular}

Magnesium. The mean magnesium concentration in the bottled water sample ranged from 0.02 to $2.5 \mathrm{mg} / \mathrm{L}$ (Table 4). The lowest concentration of magnesium was found in $\mathrm{Bw}_{20}$ and $\mathrm{Bw}_{8}$ while the highest concentration of magnesium found in $\mathrm{Bw}_{9}$. According to investigation by Mekonnen et al. [18] in different bottled waters in Gonder city, the mean concentration of magnesium ranged from $0.32 \mathrm{mg} / \mathrm{L}$ to $6.5 \mathrm{mg} / \mathrm{L}$. The mean concentration of magnesium is relatively higher than this study. The mean concentration of magnesium is compared with the range given in the labeled bottled water. The concentration of magnesium ranged from 0.08-12 $\mathrm{mg} / \mathrm{L}$ in $\mathrm{Bw}_{15}$ and $\mathrm{Bw}_{4}$, respectively and also $\mathrm{Bw}_{13}, \mathrm{Bw}_{16}, \mathrm{Bw}_{18}$ almost similar concentration of magnesium in this study but the other bottled water samples were different compared to labeled bottled water. As it was reported by Seda et al. [38] the mean concentration of magnesium in Aquaddis were $1.87 \mathrm{mg} / \mathrm{L}$ while in this study the concentration of magnesium in $\mathrm{Bw}_{3}$ was 0.45 $\mathrm{mg} / \mathrm{L}$. Therefore, the concentration of Aquaddis bottled water is higher than this study.

Sodium. In this study, sodium concentration in the bottled water samples ranged from 1.8 to $24.5 \mathrm{mg} / \mathrm{L}$ in $\mathrm{Bw}_{2}$ and $\mathrm{Bw}_{15}$, respectively (Table 4). The concentration of sodium in $\mathrm{Bw}_{1}, \mathrm{Bw}_{15}$, and $\mathrm{Bw}_{19}$ were above the WHO [15] permissible limit. The concentrations of $\mathrm{Bw}_{1}, \mathrm{Bw}_{15}$ and $\mathrm{Bw}_{19}$ were $20.2 \mathrm{mg} / \mathrm{L}, 24.5 \mathrm{mg} / \mathrm{L}$, and $24.1 \mathrm{mg} / \mathrm{L}$, respectively, whereas the recommendation of WHO is below $20 \mathrm{mg} / \mathrm{L}$ in drinking water so that $\mathrm{Bw}_{1}, \mathrm{Bw}_{15}$ and $\mathrm{Bw}_{19}$ are unfit for drinking purpose with respect to the concentration of sodium. To compare the labels of sodium in the bottled water samples maximum concentration was $24.5 \mathrm{mg} / \mathrm{L}$ in $\mathrm{Bw}_{15}$ and the minimum concentration were $0.05 \mathrm{mg} / \mathrm{L}$ in $\mathrm{Bw}_{8}$. The levels of sodium labeled on the bottled water $\mathrm{Bw}_{14}$ and $\mathrm{Bw}_{18}$ are almost similar with that found in this study but the levels of sodium labeled on the other bottled water are relatively highly different. On the other hand, Seda et al. [38] reported the mean concentration of sodium in Abyssinia, Aquaddis, and Aquasafe as $18.3 \mathrm{mg} / \mathrm{L}, 40.3$ $\mathrm{mg} / \mathrm{L}$, and $23.2 \mathrm{mg} / \mathrm{L}$, respectively. These reported concentrations of sodium in Aquaddis and 
Aquasafe were higher than the concentration of sodium found in this study and are also above the WHO recommendation while in this study, the sodium levels in the $\mathrm{Bw}_{3}$ and $\mathrm{Bw}_{4}$ bottled drinking water are below the recommendation of WHO [15]. The results are summarized in Table 4.

Potassium. The mean concentration of potassium ranged 0.14 to $8.08 \mathrm{mg} / \mathrm{L}$ in $\mathrm{Bw}_{8}$ and $\mathrm{Bw}_{18}$, respectively (Table 4). The permissible limit of potassium is $10 \mathrm{mg} / \mathrm{L}$ and $1.5 \mathrm{mg} / \mathrm{L}$, described by WHO [48] and CES [46], respectively. The concentrations of potassium in this study are below WHO permissible limit in some of the bottled water; however, it is above the limit set by CES. The concentrations of potassium at the labeled bottled water ranged 0.7 to $6.11 \mathrm{mg} / \mathrm{L}$ in $\mathrm{Bw}_{1}$ and $\mathrm{Bw}_{2}$. In this study, $\mathrm{Bw}_{1}$ and $\mathrm{Bw}_{2}$ values are $1.93 \mathrm{mg} / \mathrm{L}$ and $0.59 \mathrm{mg} / \mathrm{L}$, which are lower than the labeled at bottled water, respectively. Mekonnen et al. [18] have reported the concentration range of potassium from 1.2 to $4.1 \mathrm{mg} / \mathrm{L}$. The minimum value of the bottled water is higher than the minimum values of this study while the maximum concentration of the potassium is lower than the value of this study.

Chloride. Chloride content of 20 brands of bottles water ranged from 4.28 to $20.8 \mathrm{mg} / \mathrm{L}$. The lowest mean concentration of chloride was found in $\mathrm{Bw}_{2}$ while the highest mean concentration of chloride was found in $\mathrm{Bw}_{4}$ bottled water (Table 5), whereas the WHO [15] and CES [46] prescribed limit is $250 \mathrm{mg} / \mathrm{L}$ in drinking water. Thus all the bottled water samples are safe for drinking from the chloride point of view. To compare the concentration of chloride labeled in bottled waters relatively $\mathrm{Bw}_{2}$ and $\mathrm{Bw}_{4}$ have high chloride content than that of other brands, respectively. The chloride concentrations of bottled waters compared to the labeled of the company at the bottled water were ranged from $0.26-13 \mathrm{mg} / \mathrm{L}$ in $\mathrm{Bw}_{8}$ and $\mathrm{Bw}_{4}$, respectively. The chloride concentration reported by Reda [36] ranged from 135 to $554 \mathrm{mg} / \mathrm{L}$ in three different samples, whereas the concentration of chloride in this study is lower than the reported value Reda [36].

Table 5. The concentration of common anions $(\mathrm{mg} / \mathrm{L})$ in the bottled water samples investigated (mean \pm $\mathrm{SD})$.

\begin{tabular}{|l|c|c|c|c|c|c|}
\hline Sample & Bicarbonate & Chloride & Fluoride & Nitrate & Nitrite & Sulfate \\
\hline $\mathrm{Bw}_{1}$ & $114 \pm 2.81$ & $11.8 \pm 1.64$ & $0.62 \pm 0.06$ & $0.37 \pm 0.01$ & $0.18 \pm 0.01$ & $0.66 \pm 0.02$ \\
\hline $\mathrm{Bw}_{2}$ & $30.9 \pm 2.82$ & $4.73 \pm 0.82$ & $0.09 \pm 0.01$ & $0.06 \pm 0.02$ & $0.16 \pm 0.03$ & $0.05 \pm 0.01$ \\
\hline $\mathrm{Bw}_{3}$ & $96.0 \pm 2.82$ & $8.99 \pm 2.17$ & $1.26 \pm 0.07$ & $0.11 \pm 0.16$ & $0.18 \pm 0.01$ & $0.50 \pm 0.03$ \\
\hline $\mathrm{Bw}_{4}$ & $101 \pm 5.63$ & $20.8 \pm 0.82$ & $0.27 \pm 0.02$ & $0.84 \pm 0.52$ & $0.16 \pm 0.01$ & $1.05 \pm 0.08$ \\
\hline $\mathrm{Bw}_{5}$ & $103 \pm 4.88$ & $6.63 \pm 0.81$ & $0.16 \pm 0.01$ & $0.59 \pm 0.03$ & $0.15 \pm 0.01$ & $0.07 \pm 0.02$ \\
\hline $\mathrm{Bw}_{6}$ & $43.9 \pm 1.00$ & $8.05 \pm 2.96$ & $0.09 \pm 0.01$ & $0.04 \pm 0.01$ & $0.17 \pm 0.02$ & $0.41 \pm 0.05$ \\
\hline $\mathrm{Bw}_{7}$ & $104 \pm 2.82$ & $4.73 \pm 2.16$ & $0.18 \pm 0.01$ & $0.10 \pm 0.01$ & $0.16 \pm 0.01$ & $0.59 \pm 0.05$ \\
\hline $\mathrm{Bw}_{8}$ & $14.6 \pm 0.80$ & $5.21 \pm 1.64$ & $0.03 \pm 0.01$ & $0.30 \pm 0.03$ & $0.16 \pm 0.14$ & $1.73 \pm 0.64$ \\
\hline $\mathrm{Bw}_{9}$ & $155 \pm 2.82$ & $8.05 \pm 0.82$ & $0.69 \pm 0.02$ & $0.02 \pm 0.01$ & $0.14 \pm 0.01$ & $0.05 \pm 0.01$ \\
\hline $\mathrm{Bw}_{10}$ & $55.3 \pm 2.81$ & $5.68 \pm 2.45$ & $0.24 \pm 0.01$ & $0.04 \pm 0.01$ & $0.15 \pm 0.01$ & $0.14 \pm 0.05$ \\
\hline $\mathrm{Bw}_{11}$ & $40.7 \pm 2.82$ & $9.47 \pm 2.17$ & $0.14 \pm 0.00$ & $0.07 \pm 0.08$ & $0.08 \pm 0.04$ & $1.17 \pm 0.07$ \\
\hline $\mathrm{Bw}_{12}$ & $53.7 \pm 0.70$ & $6.63 \pm 0.82$ & $0.44 \pm 0.41$ & $0.12 \pm 0.02$ & $0.14 \pm 0.01$ & $3.84 \pm 0.02$ \\
\hline $\mathrm{Bw}_{13}$ & $69.9 \pm 2.82$ & $6.15 \pm 2.96$ & $0.33 \pm 0.03$ & $0.20 \pm 0.09$ & $0.18 \pm 0.01$ & $0.76 \pm 0.07$ \\
\hline $\mathrm{Bw}_{14}$ & $117 \pm 4.88$ & $7.57 \pm 0.82$ & $0.18 \pm 0.01$ & $0.10 \pm 0.04$ & $0.16 \pm 0.01$ & $0.50 \pm 0.05$ \\
\hline $\mathrm{Bw}_{15}$ & $202 \pm 2.82$ & $7.57 \pm 3.57$ & $0.59 \pm 0.02$ & $0.49 \pm 0.03$ & $0.17 \pm 0.01$ & $0.36 \pm 0.08$ \\
\hline $\mathrm{Bw}_{16}$ & $33.3 \pm 5.08$ & $4.26 \pm 2.46$ & $0.05 \pm 0.01$ & $0.13 \pm 0.04$ & $0.18 \pm 0.01$ & $0.44 \pm 0.03$ \\
\hline $\mathrm{Bw}_{17}$ & $149 \pm 2.82$ & $9.94 \pm 2.46$ & $0.31 \pm 0.01$ & $0.44 \pm 0.03$ & $0.15 \pm 0.04$ & $0.12 \pm 0.03$ \\
\hline $\mathrm{Bw}_{18}$ & $50.4 \pm 2.82$ & $5.68 \pm 2.46$ & $0.31 \pm 0.02$ & $0.28 \pm 0.07$ & $0.28 \pm 0.01$ & $1.76 \pm 0.26$ \\
\hline $\mathrm{Bw}_{19}$ & $174 \pm 2.82$ & $13.3 \pm 0.82$ & $0.55 \pm 0.03$ & $0.03 \pm 0.01$ & $0.28 \pm 0.07$ & $0.39 \pm 0.03$ \\
\hline $\mathrm{Bw}_{20}$ & $16.3 \pm 2.82$ & $4.26 \pm 0.20$ & $0.05 \pm 0.01$ & $0.05 \pm 0.01$ & $0.18 \pm 0.01$ & $0.05 \pm 0.01$ \\
\hline
\end{tabular}


Fluoride. The fluoride concentration of the 20 brands bottled water ranged $0.03-1.26 \mathrm{mg} / \mathrm{L}$ in $\mathrm{Bw}_{8}$ and $\mathrm{Bw}_{3}$, respectively (Table 5). The maximum concentration of fluoride recommended by WHO [15] and CES [46] is $1.5 \mathrm{mg} / \mathrm{L}$. Therefore fluoride levels in all the bottled water samples are below the permissible limit. Fluoride concentration below $1 \mathrm{mg} / \mathrm{L}$ diminishes caries reduction whereas the concentration of fluoride in all the bottled water samples were below 1 $\mathrm{mg} / \mathrm{L}$ except $\mathrm{Bw}_{3}$ bottled water with $1.26 \mathrm{mg} / \mathrm{L}$. The labeled bottled water fluoride content were $0.04,0.1,0.13,0.27,0.3,0.91 \mathrm{mg} / \mathrm{L}$ in $\mathrm{Bw}_{8}, \mathrm{Bw}_{2}, \mathrm{Bw}_{10}, \mathrm{Bw}_{1}, \mathrm{Bw}_{18}$, and $\mathrm{Bw}_{19}$, respectively, while other bottled water did not mentioned the concentration of fluoride. The concentration of fluoride in $\mathrm{Bw}_{19}$ packaged drinking water is higher than that of this study and concentration of fluoride in $\mathrm{Bw}_{1}$ brand is lower than that of this study whereas remaining bottled waters have almost similar fluoride concentration. Seda et al. [38] have reported the concentration of fluoride in bottled water in the range of 0.70 to $2.25 \mathrm{mg} / \mathrm{L}$, in that study the concentration of fluoride was above the permissible limit in Aquaddis brand water. Mekonnen et al. [18] have reported the concentration of fluoride in six bottled water which ranged 0.03-0.15 mg/L. Therefore the minimum concentrations of both studies are equal but the maximum concentration found in the present study is higher than the maximum concentration of that study.

Nitrate. The mean concentration of nitrate ranged 0.02 to $0.84 \mathrm{mg} / \mathrm{L}$ in $\mathrm{Bw}_{4}$ and $\mathrm{Bw}_{9}$, respectively (Table 5). Nitrate in all the bottled water samples were lower than the WHO recommended value of $50 \mathrm{mg} / \mathrm{L}$ [15]. The concentrations of nitrate labeled on the bottled water were (nil, 0.02, 0.03, 0.11, 0.14, 0.22, 0.45 and 3.1, mg/L) in $\mathrm{Bw}_{17}, \mathrm{Bw}_{2}, \mathrm{Bw}_{8}, \mathrm{Bw}_{13}, \mathrm{Bw}_{19}$, $\mathrm{Bw}_{16}, \mathrm{Bw}_{10}$, and $\mathrm{Bw}_{1}$, respectively, while the other bottled water were not labeled. In this study, the level of nitrate found in the above 8 bottled water were $(0.03,0.040 .06,0.13,0.2,0.3,0.37$ and $0.44 \mathrm{mg} / \mathrm{L}$ ) in $\mathrm{Bw}_{19}, \mathrm{Bw}_{10}, \mathrm{Bw}_{2}, \mathrm{~B}_{16}, \mathrm{Bw}_{13}, \mathrm{Bw}_{8}, \mathrm{Bw}_{1}, \mathrm{Bw}_{17}$, respectively (Table 5). The concentration of nitrate found in this study and nitrate labeled on bottled water are almost similar except $\mathrm{Bw}_{1}$ and $\mathrm{B}_{17}$ of bottled water. The labeled value of $\mathrm{Bw}_{1}$ bottled water was higher than the present study while the $\mathrm{Bw}_{17}$ bottled drinking water was nil but this study found 0.44 $\mathrm{mg} / \mathrm{L}$. According to Mekonnen et al. [18], analysis of six brands of bottled water, the nitrate levels of the three brands were $0.251 \mathrm{mg} / \mathrm{L}, 0.389 \mathrm{mg} / \mathrm{L}, 0.33 \mathrm{mg} / \mathrm{L}$ in brand 1, brand 2, brand 3, respectively, while in the other three brands nitrate was not detected but in this study nitrate was found in all the bottled waters. Nitrate content in $\mathrm{Bw}_{1}$ and brand 2 mineral water are almost similar.

Nitrite. The mean concentration of nitrite was in the range $0.08-0.28 \mathrm{mg} / \mathrm{L}$ (Table 5). The highest mean concentration of nitrite was found in $\mathrm{Bw}_{18}$ and $\mathrm{Bw}_{19}$ whereas the lowest mean concentration of nitrite was found in $\mathrm{Bw}_{11}$. The nitrite concentrations were not labeled on bottled water but this study observed the concentration of nitrite in bottled water. The recommendations of WHO [15] and CES [46] are below $3 \mathrm{mg} / \mathrm{L}$ nitrite. Thus the concentration of nitrite in bottled water is safe for drinking purpose. Simeonova et al. [49] have reported the concentration of nitrite in drinking water in the range $0.01-1.56 \mathrm{mg} / \mathrm{L}$. The maximum concentration of nitrite in drinking water is higher than the present study of bottled drinking water. However, the minimum concentrations of those studies were $0.01 \mathrm{mg} / \mathrm{L}$ which is smaller than the value of this study.

Bicarbonate. The mean concentration of bicarbonate ranged 16.3 to $202 \mathrm{mg} / \mathrm{L}$ in $\mathrm{Bw}_{20}$ and $\mathrm{Bw}_{15}$, respectively (Table 5). The maximum concentration limit of bicarbonate set by WHO is $500 \mathrm{mg} / \mathrm{L}$ [15]. The concentration of bicarbonate found in this study is acceptable for drinking purpose. Rakotondrabe et al. [25] have reported the concentration of bicarbonate ranged from 1.77 to $59.3 \mathrm{mg} / \mathrm{L}$ which are much lower than the concentration of bicarbonate found in drinking water of this study. This study has found a higher concentration of bicarbonate in bottled drinking water compared with the labeled on the bottled water. 
Sulfate. The mean concentrations of sulfate ranged 0.05-3.84 mg/L in $\mathrm{Bw}_{20}, \mathrm{Bw}_{9}$ and $\mathrm{Bw}_{2}($ Table $5)$. The highest mean concentration of sulfate was found in $\mathrm{Bw}_{2}$ while the lowest mean concentration was found in $\mathrm{Bw}_{20}$ and $\mathrm{Bw}_{9}$ (Table 5). The WHO [15] and CES [46] have recommended sulfate concentration below $250 \mathrm{mg} / \mathrm{L}$ in drinking water. Thus the sulfate levels in all the bottled drinking water is below the permissible limit and the bottled water samples are safe for drinking purpose with respect to sulfate. Mihayo and Mkoma [23] have reported a maximum concentration of sulfate, $48.2 \mathrm{mg} / \mathrm{L}$ and the minimum concentration of sulfate, 2.5 $\mathrm{mg} / \mathrm{L}$; these concentrations of sulfate are higher than this study.

\section{Correlation}

Pearson correlation [50] for various water quality parameters in the bottled water brands studied in this work was evaluated which revealed strong correlations for most of the constituents suggesting that they may originate predominantly from the same source. Higher correlations $\left(\mathrm{r}^{2}\right.$ $>0.80$ ) were observed in TDS with alkalinity, bicarbonate and hardness. Whereas EC and TDS had very high correlation $\left(\mathrm{r}^{2}=1\right)$. In addition there was also a high correlation of EC with total alkalinity, total hardness, bicarbonate and total hardness $\left(\mathrm{r}^{2}>90\right)$. EC has also correlation with calcium, magnesium, sodium and chloride. Total hardness had higher correlation with magnesium and calcium and also correlated with total alkalinity and bicarbonate. Total alkalinity was highly correlated with bicarbonate $\left(r^{2}=1\right)$ and also correlated with sodium, magnesium and calcium. $\mathrm{pH}$ correlated with electrical conductivity, total alkalinity, bicarbonate and also bicarbonate correlated with magnesium and calcium. Fluoride correlated with sodium on the other hand calcium highly correlated with magnesium and bicarbonate with total alkalinity were highly correlated indicates the concentration of total alkalinity described by bicarbonate. TDS have showed high positive correlation to all the individual parameters and its correlation is significant at $99 \%$ confidence level, except nitrite. $\mathrm{pH}$ with fluoride, chloride, and potassium pairs positively correlated significantly at $95 \%$ confidence level. CEC except nitrite and sulfate was highly positively correlated with most parameter significantly at $99 \%$ confidence level. Generally almost all parameters pairs were significantly correlated at $99 \%$ and $95 \%$ confidence levels.

The comparison of chemical and physical parameters of bottled water samples among each other

Among the 20 brands of bottled water samples, highest $\mathrm{pH}$ value was found in $\mathrm{Bw}_{1}$ and the lowest $\mathrm{pH}$ value was found in $\mathrm{Bw}_{16}$. Among the 20 brands of bottled water samples highest electrical conductivity and the highest total dissolved solid were found in $\mathrm{Bw}_{15}$ bottled water sample. Whereas electrical conductivity and total dissolved solid were lowest in $\mathrm{Bw}_{8}$ and $\mathrm{Bw}_{20}$ bottled water samples, respectively. In addition, $\mathrm{Bw}_{3}$ and $\mathrm{Bw}_{16}$ have almost similar electrical conductivity and total dissolved solid. The concentration of total alkalinity in $\mathrm{Bw}_{6}$ bottled water samples was higher than the other bottled water samples and also the concentration of bicarbonate in $\mathrm{Bw}_{15}$ was higher than all the other bottled water samples. The total hardness in $\mathrm{Bw}_{4}$ was higher than the other bottled water samples. The total hardness, alkalinity and bicarbonate concentration in $\mathrm{Bw}_{8}$ and $\mathrm{Bw}_{20}$ bottled water samples were lower than the other bottled drinking water samples.

The concentration of nitrate in $\mathrm{Bw}_{4}$ and $\mathrm{Bw}_{5}$ of bottled water was higher values compared to other bottled water samples. The highest concentration of sulfate was found in $\mathrm{Bw}_{12}$ bottled drinking water whereas the highest concentration of nitrite was found in $\mathrm{Bw}_{18}$ and $\mathrm{Bw}_{19}$ compared to other bottled water. The lowest concentration of sulfate was found in $\mathrm{Bw}_{2}, \mathrm{Bw}_{5}$, $\mathrm{Bw}_{9}$ and $\mathrm{Bw}_{20}$ bottled drinking water. Concentration of fluoride in $\mathrm{Bw}_{3}$ bottled water was higher and the lowest concentration of fluoride was found in $\mathrm{Bw}_{8}, \mathrm{Bw}_{16}$, and $\mathrm{Bw}_{20}$ bottled water samples. Concentration of chloride in $\mathrm{Bw}_{4}$ bottled water had higher value and the lowest 
concentration of chloride was found in $\mathrm{Bw}_{2}, \mathrm{Bw}_{8}, \mathrm{Bw}_{16}$ and $\mathrm{Bw}_{20}$ bottled water samples. The concentrations of sodium in $\mathrm{Bw}_{15}$ and $\mathrm{Bw}_{19}$ bottled water were higher than the other bottled drinking water. The lowest concentration of sodium was found in $\mathrm{Bw}_{2}$ and $\mathrm{Bw}_{20}$ bottled water. The concentration of magnesium was higher in $\mathrm{Bw}_{4}$ and $\mathrm{Bw}_{9}$ and the lowest concentration of magnesium was in $\mathrm{Bw}_{8}, \mathrm{Bw}_{16}$ and $\mathrm{Bw}_{20}$ when compared to all the bottled water samples. The concentration of potassium was higher in $\mathrm{Bw}_{19}$ while the lowest concentration was found in $\mathrm{Bw}_{8}, \mathrm{Bw}_{16}$, and $\mathrm{Bw}_{20}$ of bottled water.

\section{Calculation of water quality index of bottled drinking water}

The bottled drinking water can be classified into five quality levels (excellent, good, poor, very poor and unstable) according to the water quality index [26-31]. The water quality index (WQI) was calculated by using the standards of the drinking water quality recommended by the WHO. The water quality index was calculated based weighted arithmetic method using various physicochemical parameters in different bottled water [45]. The results of water quality index in this study were found in the range of 3.85-49.2. Thus, all the bottled water samples analyzed in this study were grouped in either excellent or good water quality level. The details of calculation of water quality index are given in Table 6. Figure 1 shows the water quality index of the studied bottles water. Among the 20 brands of bottled waters studied, $75 \%$ of bottled water samples fall in excellent water quality while $25 \%$ of bottled water lies within good water quality.

Table 6. Calculation of the water quality index of bottled water samples.

\begin{tabular}{|l|c|c|c|c|c|c|c|c|c|c|}
\hline Samples & $\mathrm{Bw}_{1}$ & $\mathrm{Bw}_{2}$ & $\mathrm{Bw}_{3}$ & $\mathrm{Bw}_{4}$ & $\mathrm{Bw}_{5}$ & $\mathrm{Bw}_{6}$ & $\mathrm{Bw}_{7}$ & $\mathrm{Bw}_{8}$ & $\mathrm{Bw}_{9}$ & $\mathrm{Bw}_{10}$ \\
\hline$\Sigma$ Wi & 1.33 & 1.33 & 1.33 & 1.33 & 1.33 & 1.33 & 1.33 & 1.33 & 1.33 & 1.33 \\
\hline$\Sigma$ qiWi & 43.1 & 7.19 & 65.6 & 19.1 & 12.0 & 9.64 & 12.2 & 4.39 & 36.4 & 15.1 \\
\hline WQI $=\Sigma q i W i / \Sigma W i$ & 32.3 & 5.39 & 49.2 & 14.3 & 9.00 & 7.22 & 9.18 & 3.29 & 27.3 & 11.3 \\
\hline Grade & $\mathrm{B}$ & $\mathrm{A}$ & $\mathrm{B}$ & $\mathrm{A}$ & $\mathrm{A}$ & $\mathrm{A}$ & $\mathrm{A}$ & $\mathrm{A}$ & $\mathrm{B}$ & $\mathrm{A}$ \\
\hline Samples & $\mathrm{Bw}_{11}$ & $\mathrm{Bw}_{12}$ & $\mathrm{Bw}_{13}$ & $\mathrm{Bw}_{14}$ & $\mathrm{Bw}_{15}$ & $\mathrm{Bw}_{16}$ & $\mathrm{Bw}_{17}$ & $\mathrm{Bw}_{18}$ & $\mathrm{Bw}_{19}$ & $\mathrm{Bw}_{20}$ \\
\hline$\Sigma$ Wi & 1.33 & 1.33 & 1.33 & 1.33 & 1.33 & 1.33 & 1.33 & 1.33 & 1.33 & 1.33 \\
\hline$\Sigma$ qiWi & 10.2 & 24.2 & 20.2 & 17.4 & 36.4 & 6.97 & 21.7 & 21.9 & 42.3 & 5.14 \\
\hline WQI $=\Sigma q i W i / \Sigma W i$ & 7.61 & 18.1 & 15.1 & 13.0 & 27.3 & 5.2 & 16.3 & 16.4 & 31.7 & 3.85 \\
\hline Grade & $\mathrm{A}$ & $\mathrm{A}$ & $\mathrm{A}$ & $\mathrm{A}$ & $\mathrm{B}$ & $\mathrm{A}$ & $\mathrm{A}$ & $\mathrm{A}$ & $\mathrm{B}$ & $\mathrm{A}$ \\
\hline
\end{tabular}
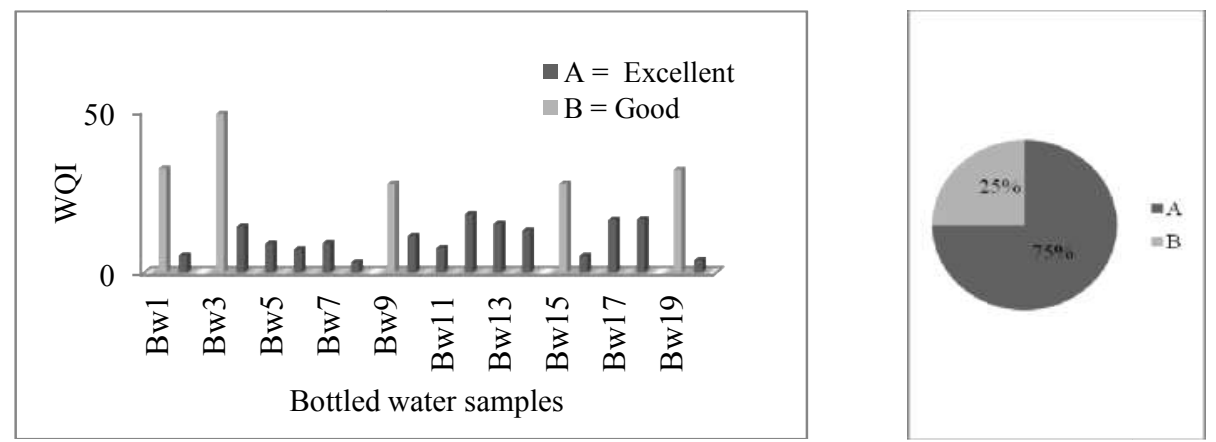

Figure 1. The water quality index of bottled water samples. 
Comparison of the results of physicochemical parameters with the labeled values on the bottled water samples

Table 7. Comparison of physicochemical parameters $(\mathrm{mg} / \mathrm{L})$ found in this study with labeled values of the bottled water samples (EC in $\mu \mathrm{s} / \mathrm{cm}$ ).

\begin{tabular}{|c|c|c|c|c|c|c|c|c|c|c|c|c|c|c|c|}
\hline \multirow[b]{2}{*}{ Sample } & \multicolumn{2}{|c|}{ TDS } & \multicolumn{2}{|c|}{$\mathrm{pH}$} & EC & \multicolumn{2}{|c|}{ TH } & \multicolumn{2}{|c|}{ TA } & \multicolumn{2}{|c|}{$\mathrm{HCO}_{3}{ }^{-}$} & \multicolumn{2}{|c|}{$\mathrm{Cl}^{-}$} & \multicolumn{2}{|c|}{$\mathrm{F}^{-}$} \\
\hline & $\mathrm{M}$ & $\mathrm{L}$ & $\mathrm{M}$ & $\mathrm{L}$ & $\mathrm{M}$ & $\mathrm{M}$ & $\mathrm{L}$ & $\mathrm{M}$ & $\mathrm{L}$ & $\mathrm{M}$ & $\mathrm{L}$ & $\mathrm{M}$ & $\mathrm{L}$ & $\mathrm{M}$ & $\mathrm{L}$ \\
\hline $\mathrm{Bw}_{1}$ & 87.3 & 149 & 7.69 & 7.4 & 186 & 46.0 & - & 93.3 & - & 114 & 134 & 11.8 & 7.50 & 0.62 & 0.27 \\
\hline $\mathrm{Bw}_{2}$ & 19.0 & 21.4 & 6.97 & 7.00 & 41.1 & 14.7 & 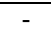 & 25.3 & - & 30.9 & 6.00 & 4.73 & 1.99 & 0.09 & 0.10 \\
\hline $\mathrm{Bw}_{3}$ & 66.3 & 82.0 & 7.03 & 7.00 & 139 & 20.0 & - & 78.7 & - & 96.0 & 73.2 & 8.99 & 7.60 & 1.26 & - \\
\hline $\mathrm{Bw}_{4}$ & 123 & 170 & 7.11 & 7.20 & 256 & 97.3 & - & 82.7 & - & 101 & 84.0 & 20.8 & 13.0 & 0.27 & - \\
\hline $\mathrm{Bw}_{5}$ & 76.3 & 144 & 7.22 & 7.24 & 161 & 54.7 & - & 84.0 & - & 103 & 64.8 & 6.63 & 6.38 & 0.16 & - \\
\hline $\mathrm{Bw}_{6}$ & 28.7 & 20.3 & 7.37 & 7.00 & 60.6 & 9.33 & - & 360 & 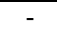 & 43.9 & 3.01 & 8.05 & 6.07 & 0.09 & - \\
\hline $\mathrm{Bw}_{7}$ & 66.0 & 135 & 7.35 & 7.60 & 139 & 60.0 & 13.8 & 85.3 & - & 104 & - & 4.73 & 5.60 & 0.18 & - \\
\hline $\mathrm{Bw}_{8}$ & 7.00 & 8.43 & 7.20 & 7.00 & 15.1 & 8.00 & 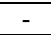 & 12.0 & 8.33 & 14.6 & 8.41 & 5.21 & 0.26 & 0.03 & 0.04 \\
\hline $\mathrm{Bw}_{9}$ & 107 & 85.0 & 7.48 & 7.32 & 225 & 96.0 & - & 127 & 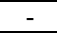 & 155 & 146 & 8.05 & 6.03 & 0.69 & - \\
\hline $\mathrm{Bw}_{10}$ & 34.7 & 54.5 & 7.30 & 7.92 & 72.1 & 24.0 & - & 45.0 & 0.69 & 55.0 & - & 5.68 & 1.7 .0 & 0.24 & 0.13 \\
\hline $\mathrm{Bw}_{11}$ & 31.0 & 70.0 & 6.94 & 7.10 & 65.9 & 26.7 & - & 33.3 & 30 & 40.7 & 60.5 & 9.47 & 4.00 & 0.14 & 0.50 \\
\hline $\mathrm{Bw}_{12}$ & 38.0 & 155 & 7.04 & 7.00 & 80.0 & 32.0 & - & 44.0 & - & 53.7 & - & 6.63 & - & 0.44 & - \\
\hline $\mathrm{Bw}_{13}$ & 46.0 & 50.0 & 7.60 & 7.40 & 96.3 & 16.0 & - & 57.0 & - & 69.9 & 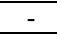 & 6.15 & 4.82 & 0.33 & - \\
\hline $\mathrm{Bw}_{14}$ & 80.7 & 134 & 7.36 & 7.18 & 170 & 42.7 & - & 96.0 & - & 117 & - & 7.57 & 5.67 & 0.18 & - \\
\hline $\mathrm{Bw}_{15}$ & 139 & 33.0 & 7.29 & 7.10 & 289 & 44.0 & - & 165 & - & 202 & 25.9 & 7.57 & 2.6 & 0.59 & - \\
\hline $\mathrm{Bw}_{16}$ & 18.0 & 30.0 & 6.43 & 7.00 & 38.9 & 12.0 & - & 27.3 & 7 & 33.3 & 11.2 & 4.26 & 5.53 & 0.05 & - \\
\hline $\mathrm{Bw}_{17}$ & 102 & 155 & 7.56 & 7.00 & 215 & 74.7 & - & 123 & 104 & 149 & 126 & 9.94 & 6.27 & 0.31 & 0.30 \\
\hline $\mathrm{Bw}_{18}$ & 37.3 & 130 & 7.03 & 7.00 & 78.7 & 17.3 & - & 41.3 & 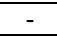 & 50.4 & 12.1 & 5.68 & 10.64 & 0.31 & 0 \\
\hline $\mathrm{Bw}_{19}$ & 127 & 65.0 & 7.55 & 7.05 & 266 & 46.7 & - & 143 & 85 & 174 & - & 13.3 & 4.50 & 0.55 & 0.91 \\
\hline $\mathrm{Bw}_{20}$ & 4.67 & 10.0 & 6.52 & 7.00 & 9.87 & 4.00 & - & 13.3 & & 16.3 & 1.00 & 4.26 & 1.4 & 0.05 & \\
\hline
\end{tabular}

\begin{tabular}{|c|c|c|c|c|c|c|c|c|c|c|c|c|c|}
\hline \multirow[b]{2}{*}{ Sample } & \multicolumn{2}{|c|}{$\mathrm{NO}_{3}{ }^{-}$} & \multirow{2}{*}{$\frac{\mathrm{NO}_{2}{ }^{-}}{\mathrm{M}}$} & \multicolumn{2}{|c|}{$\mathrm{SO}_{4}{ }^{2-}$} & \multicolumn{2}{|c|}{$\mathrm{Ca}^{2+}$} & \multicolumn{2}{|c|}{$\mathrm{Mg}^{2+}$} & \multicolumn{2}{|c|}{$\mathrm{K}^{+}$} & \multicolumn{2}{|c|}{$\mathrm{Na}^{+}$} \\
\hline & $\mathrm{M}$ & $\mathrm{L}$ & & $\mathrm{M}$ & $\mathrm{L}$ & $\mathrm{M}$ & $\mathrm{L}$ & $\mathrm{M}$ & $\mathrm{L}$ & $\mathrm{M}$ & $\mathrm{L}$ & $\mathrm{M}$ & $\mathrm{L}$ \\
\hline $\mathrm{Bw}_{1}$ & 0.37 & 3.10 & 0.18 & 0.66 & - & 4.30 & 12.0 & 1.11 & 3.40 & 1.93 & 0.70 & 20.2 & 5.40 \\
\hline $\mathrm{Bw}_{2}$ & 0.06 & 0.02 & 0.16 & 0.05 & 4.40 & 1.18 & 3.21 & 0.42 & 1.95 & 0.59 & 6.11 & 1.80 & 3.30 \\
\hline $\mathrm{Bw}_{3}$ & 0.11 & - & 0.18 & 0.50 & - & 1.54 & 3.20 & 0.45 & 1.95 & 2.14 & 1.65 & 19.7 & 1.08 \\
\hline $\mathrm{Bw}_{4}$ & 0.84 & - & 0.16 & 1.05 & 4.00 & 7.93 & 21.0 & 2.30 & 12.0 & 2.05 & 3.60 & 7.39 & 16.0 \\
\hline $\mathrm{Bw}_{5}$ & 0.59 & - & 0.15 & 0.07 & - & 4.65 & 15.4 & 0.67 & 1.92 & 0.46 & 0.68 & 9.55 & 8.47 \\
\hline $\mathrm{Bw}_{6}$ & 0.04 & - & 0.17 & 0.41 & - & 0.34 & 0.20 & 0.55 & 0.10 & 0.38 & 1.05 & 9.51 & 0.15 \\
\hline $\mathrm{Bw}_{7}$ & 0.10 & - & 0.16 & 0.59 & - & 3.40 & 5.10 & 2.15 & 0.94 & 1.11 & 2.42 & 3.91 & 12.7 \\
\hline $\mathrm{Bw}_{8}$ & 0.30 & 0.03 & 0.16 & 1.73 & 0.30 & 0.19 & 1.14 & 0.02 & 0.32 & 0.14 & 1.94 & 4.20 & 0.05 \\
\hline $\mathrm{Bw}_{9}$ & 0.02 & - & 0.14 & 0.05 & - & 8.09 & 5.76 & 2.51 & 2.68 & 1.28 & 0.84 & 9.16 & 3.80 \\
\hline $\mathrm{Bw}_{10}$ & 0.04 & 0.45 & 0.15 & 0.14 & 0.10 & 1.72 & 5.74 & 0.56 & 1.39 & 1.43 & 0.39 & 4.68 & 2.60 \\
\hline $\mathrm{Bw}_{11}$ & 0.07 & 1.00 & 0.08 & 1.17 & 3.00 & 1.85 & 10.5 & 0.59 & 5.00 & 1.99 & 1.20 & 3.60 & 4.80 \\
\hline $\mathrm{Bw}_{12}$ & 0.12 & - & 0.14 & 3.84 & - & 2.41 & 17.5 & 0.78 & 4.60 & 1.95 & 3.60 & 3.74 & 7.20 \\
\hline $\mathrm{Bw}_{13}$ & 0.20 & 0.11 & 0.18 & 0.76 & 0 & 0.76 & 1.92 & 0.35 & 0.67 & 0.29 & 0.37 & 11.8 & 3.00 \\
\hline $\mathrm{Bw}_{14}$ & 0.10 & - & 0.16 & 0.50 & - & 3.34 & 1.50 & 1.01 & 0.40 & 3.90 & 3.85 & 13.2 & 12.6 \\
\hline $\mathrm{Bw}_{15}$ & 0.49 & - & 0.17 & 0.36 & - & 2.49 & 0.11 & 1.13 & 0.08 & 1.51 & 0.20 & 24.5 & 9.40 \\
\hline $\mathrm{Bw}_{16}$ & 0.13 & 0.22 & 0.18 & 0.44 & - & 0.44 & 0.21 & 0.10 & 0.14 & 0.77 & 0.28 & 7.28 & 2.70 \\
\hline $\mathrm{Bw}_{17}$ & 0.44 & Nil & 0.15 & 0.12 & 1.50 & 6.14 & 26.8 & 2.10 & 7.20 & 2.10 & 3.30 & 14.5 & 7.70 \\
\hline $\mathrm{Bw}_{18}$ & 0.28 & - & 0.28 & 1.76 & - & 1.26 & 3.15 & 0.56 & 0.80 & 3.15 & 2.00 & 6.87 & 3.65 \\
\hline $\mathrm{Bw}_{19}$ & 0.03 & 0.14 & 0.28 & 0.39 & - & 2.03 & 18.1 & 1.48 & 10.0 & 8.08 & 4.00 & 24.1 & 24.0 \\
\hline $\mathrm{Bw}_{20}$ & 0.05 & - & 0.18 & 0.05 & 1.20 & 0.26 & 1.20 & 0.02 & 0.80 & 0.21 & 0.70 & 2.45 & 1.20 \\
\hline
\end{tabular}

$\mathrm{M}$ and $\mathrm{L}$ indicate measured in this study and labeled at bottled water, respectively.

The results of physicochemical parameters of the bottled water samples were compared with the values labeled in the bottles (Table 7). Some of the parameters such as electrical conductivity, total hardness, total alkanity and fluoride are either not labeled at all or labeled only in few 
brands of bottled water. There is a wide variation in the values of physicochemical parameters of the bottled water samples between the measured values and labeled values. These variations clearly emphasize that there is need of regulation about the monitoring of labeled values.

Comparison of the physicochemical parameters of the bottled water samples of this study with literature values

The results of physicochemical parameters of the bottled water samples were compared with the permissible levels recommended by the guidelines for drinking water quality (Table 8). The comparison of this study with WHO [15] and Ethiopian standards [46] showed that the concentrations of physicochemical parameters in almost all the bottled drinking water are below the permissible limit except sodium, potassium, and $\mathrm{pH}$.

Table 8. Comparison of physicochemical parameters $(\mathrm{mg} / \mathrm{L})$ of the present study with WHO and CES recommended values (EC in $\mu \mathrm{s} / \mathrm{cm})$.

\begin{tabular}{|c|c|c|c|c|c|c|c|c|c|c|c|c|c|c|c|}
\hline Sample & TDS & $\mathrm{pH}$ & $\mathrm{EC}$ & $\mathrm{TH}$ & TA & $\mathrm{HCO}_{3}{ }^{-}$ & $\mathrm{Cl}^{-}$ & $\mathrm{F}^{-}$ & $\mathrm{NO}_{3}{ }^{-}$ & $\mathrm{NO}_{2}^{-}$ & $\mathrm{SO}_{4}{ }^{2-}$ & $\mathrm{Ca}^{2+}$ & $\mathrm{Mg}^{2+}$ & $\mathrm{K}^{+}$ & $\mathrm{Na}^{+}$ \\
\hline $\mathrm{Bw}_{1}$ & 87.3 & 7.69 & 186 & \begin{tabular}{|l|}
46.0 \\
\end{tabular} & 93.3 & 114. & 11.8 & 0.62 & 0.37 & 0.18 & 0.66 & 4.30 & 1.11 & 1.93 & 20.2 \\
\hline $\mathrm{Bw}_{2}$ & 19.0 & 6.97 & 41.1 & 14.7 & 25.3 & 30.9 & 4.73 & 0.09 & 0.06 & 0.16 & 0.05 & 1.18 & 0.42 & 0.59 & 1.80 \\
\hline $\mathrm{Bw}_{3}$ & 66.3 & 7.03 & 139 & \begin{tabular}{|l|}
20.0 \\
\end{tabular} & 78.7 & 96.0 & 8.99 & 1.26 & 0.11 & 0.18 & 0.50 & 1.54 & 0.45 & 2.14 & 19.7 \\
\hline $\mathrm{Bw}_{4}$ & 123 & 7.11 & 256 & 97.3 & 82.7 & 101 & 20.8 & 0.27 & 0.84 & 0.16 & 1.05 & 7.93 & 2.30 & 2.05 & 7.39 \\
\hline $\mathrm{Bw}_{5}$ & 76.3 & 7.22 & 161 & 54.7 & 84.0 & 103 & 6.63 & 0.16 & 0.59 & 0.15 & 0.07 & 4.65 & 0.67 & 0.46 & 9.55 \\
\hline $\mathrm{Bw}_{6}$ & 28.7 & 7.37 & 60.6 & \begin{tabular}{|l|}
9.33 \\
\end{tabular} & 360 & 43.9 & 8.05 & 0.09 & .04 & 0.17 & 0.41 & 0.34 & 0.55 & 0.38 & 9.51 \\
\hline $\mathrm{Bw}_{7}$ & 66.0 & 7.35 & 139 & \begin{tabular}{|l|}
60.0 \\
\end{tabular} & 85.3 & 104 & 4.73 & 0.18 & 0.10 & 0.16 & 0.59 & 3.40 & 2.15 & 1.11 & 3.91 \\
\hline $\mathrm{Bw}_{8}$ & 7.00 & 7.20 & 15.1 & \begin{tabular}{|l|}
8.00 \\
\end{tabular} & 12.0 & 14.6 & 5.21 & 0.03 & 0.30 & 0.16 & 1.73 & 0.19 & 0.02 & 0.14 & 4.20 \\
\hline $\mathrm{Bw}_{9}$ & 107 & 7.48 & 225 & 96.0 & 127 & 155 & 8.05 & 0.69 & 0.02 & 0.14 & 0.05 & 8.09 & 2.51 & 1.28 & 9.16 \\
\hline $\mathrm{Bw}_{10}$ & 34.7 & 7.30 & 72.1 & 24.0 & 45.0 & 55.0 & 5.68 & 0.24 & 0.04 & 0.15 & 0.14 & 1.72 & 0.56 & 1.43 & 4.68 \\
\hline $\mathrm{Bw}_{11}$ & 31.0 & 6.94 & 65.9 & 26.7 & 33.3 & 40.7 & 9.47 & 0.14 & 0.07 & 0.08 & 1.17 & 1.85 & 0.59 & 1.99 & 3.60 \\
\hline $\mathrm{Bw}_{12}$ & 38.0 & 7.04 & 80.0 & \begin{tabular}{|l|}
32.0 \\
\end{tabular} & 44.0 & 53.7 & 6.63 & 0.44 & 0.12 & 0.14 & 3.84 & 2.41 & 0.78 & 1.95 & 3.74 \\
\hline $\mathrm{Bw}_{13}$ & 46.0 & 7.60 & 96.3 & \begin{tabular}{|l|}
16.0 \\
\end{tabular} & 57.0 & 69.9 & 6.15 & 0.33 & 0.20 & 0.18 & 0.76 & 0.76 & 0.35 & 0.29 & 11.8 \\
\hline $\mathrm{Bw}_{14}$ & 80.7 & 7.36 & 170 & \begin{tabular}{|l|}
42.7 \\
\end{tabular} & 96.0 & 117 & 7.57 & 0.18 & 0.10 & 0.16 & 0.50 & 3.34 & 1.01 & 3.90 & 13.2 \\
\hline $\mathrm{Bw}_{15}$ & 139 & 7.29 & 289 & \begin{tabular}{|l|}
44.0 \\
\end{tabular} & 165 & 202 & 7.57 & 0.59 & 0.49 & 0.17 & 0.36 & 2.49 & 1.13 & 1.51 & 24.5 \\
\hline $\mathrm{Bw}_{16}$ & 18.0 & 6.43 & 38.9 & 12.0 & 27.3 & 33.3 & 4.26 & 0.05 & 0.13 & 0.18 & 0.44 & 0.44 & 0.10 & 0.77 & 7.28 \\
\hline $\mathrm{Bw}_{17}$ & 102 & 7.56 & 215 & \begin{tabular}{|l|}
74.7 \\
\end{tabular} & 123 & 149 & 9.94 & 0.31 & 0.44 & 0.15 & 0.12 & 6.14 & 2.10 & 2.10 & 14.5 \\
\hline $\mathrm{Bw}_{18}$ & 37.3 & 7.03 & 78.7 & \begin{tabular}{|l|}
17.3 \\
\end{tabular} & 41.3 & 50.4 & 5.68 & 0.31 & 0.28 & 0.28 & 1.76 & 1.26 & 0.56 & 3.15 & 6.87 \\
\hline $\mathrm{Bw}_{19}$ & 127 & 7.55 & 266 & \begin{tabular}{|l|}
46.7 \\
\end{tabular} & 143 & 174. & 13.3 & 0.55 & 0.03 & 0.28 & 0.39 & 2.03 & 1.48 & 8.08 & 24.1 \\
\hline $\mathrm{Bw}_{20}$ & 4.67 & 6.52 & 9.87 & \begin{tabular}{|l|}
4.00 \\
\end{tabular} & 13.3 & 16.3 & 4.26 & 0.05 & 0.05 & 0.18 & 0.05 & 0.26 & 0.02 & 0.21 & 2.45 \\
\hline Mean & 61.9 & 7.20 & 130 & \begin{tabular}{|l|}
37.3 \\
\end{tabular} & 70.6 & 86.2 & 7.98 & 0.33 & 0.22 & 0.18 & 0.73 & 2.71 & 0.94 & 1.77 & 10.1 \\
\hline Max & 139 & 7.69 & 289 & \begin{tabular}{|l|}
97.0 \\
\end{tabular} & 116 & 202 & 20.8 & 1.26 & 0.84 & 0.28 & 3.84 & 8.09 & 2.51 & 8.08 & 24.5 \\
\hline Min & 4.67 & 6.43 & 9.87 & 4.00 & 12.0 & 16.3 & 4.26 & 0.03 & 0.02 & 0.08 & 0.05 & 0.19 & 0.02 & 0.14 & 1.80 \\
\hline WHO & 500 & $6.5-8.5$ & 1000 & \begin{tabular}{|l|}
500 \\
\end{tabular} & 200 & 500 & 250 & 1.50 & 50.0 & 3.00 & 250 & 200 & 150 & 10.0 & 20.0 \\
\hline CES & 1000 & $6.5-8.5$ & - & 300 & 200 & - & 250 & 1.50 & 50.0 & 3.00 & 250 & 75 & 50 & 1.50 & 200 \\
\hline
\end{tabular}

Comparison of the results of a present study with the results reported in the literature is summarized in Table 9. There is a wide variation in the values of physicochemical parameters of the bottled water samples of the present study with that from different countries and with that of other studies in Ethiopia. This is due to the fact that guidelines vary from country to country but also due to the fact that the original source of water is different due to the variation in geographical and climatic conditions. These variations are despite of the fact that every country follows the general guidelines of WHO [15]. 
Table 9. Comparison of the physicochemical parameters $(\mathrm{mg} / \mathrm{L})$ of the bottled water samples of this study with literature values $(\mathrm{EC}$ in $\mu \mathrm{s} / \mathrm{cm})$.

\begin{tabular}{|l|c|c|c|c|c|c|c|c|c|}
\hline \multirow{2}{*}{ Country } & TDS & $\mathrm{pH}$ & $\mathrm{EC}$ & $\mathrm{TH}$ & $\mathrm{TA}$ & $\mathrm{HCO}_{3}^{-}$ & $\mathrm{Cl}^{-}$ & $\mathrm{F}^{-}$ & Reference \\
\cline { 2 - 10 } & $4.67-139$ & $6.43-7.69$ & $9.87-289$ & $4.00-97.0$ & $12.0-116$ & $16.3-202$ & $4.26-20.8$ & 0.031 .26$. & This study \\
\hline Ethiopia & - & $6.50-8.34$ & $120-1788$ & - & - & - & $3.57-48.1$ & $0.00-0.92$ & {$[38]$} \\
\hline Ethiopia & - & - & - & - & - & - & $0.4-6.3$ & $0.03-0.15$ & {$[18]$} \\
\hline Tanzania & $7.80-126$ & $7.3-7.6$ & $17.4-280$ & $20-66.5$ & $16.0-79.0$ & - & $2.5-48.2$ & - & {$[23]$} \\
\hline $\begin{array}{l}\text { Mutah, } \\
\text { Jordan }\end{array}$ & $210-978$ & $6.70-8.20$ & $177-1494$ & $3.90-136.9$ & $12.9-289$ & - & $4.6-150$ & $0.01-1.60$ & {$[21]$} \\
\hline $\begin{array}{l}\text { Kirkuk } \\
\text { Iraq }\end{array}$ & $90.0-260$ & $7.30-8.00$ & $140-464$ & $45.0-190$ & $44-190$ & - & $5.97-28.8$ & - & {$[16]$} \\
\hline $\begin{array}{l}\text { Saudi } \\
\text { Arabia }\end{array}$ & $100-253$ & $7.00-8.00$ & - & $15.0-110$ & - & $1.30-120$ & $1.00-68.0$ & $0.00-1.20$ & {$[9]$} \\
\hline Italy & - & $4.10-8.80$ & $18.0-4090$ & $0.30-105$ & - & $3.5-1875$ & $0.20-323$ & $0.01-7.93$ & {$[24]$} \\
\hline
\end{tabular}

\begin{tabular}{|l|c|c|c|c|c|c|c|c|}
\hline Country & $\mathrm{NO}_{3}{ }^{-}$ & $\mathrm{NO}_{2}^{-}$ & $\mathrm{SO}_{4}{ }^{2-}$ & $\mathrm{Ca}^{2+}$ & $\mathrm{Mg}^{2+}$ & $\mathrm{K}^{+}$ & $\mathrm{Na}^{+}$ & Reference \\
\hline & $0.02-0.84$ & $0.08-028$ & $0.05-3.84$ & $0.19-8.09$ & $0.02-2.51$ & $0.14-8.08$ & $1.80-24.5$ & This study \\
\hline Ethiopia & $0.00-13.9$ & - & $0.00-90.6$ & $1.51-51.4$ & $1.30-21.9$ & $1.19-36.3$ & $2.77-195$ & {$[38]$} \\
\hline Ethiopia & $0.25-0.39$ & - & $0.06-4.02$ & $3.00-28.3$ & $0.32-6.5$ & $1.2-4.1$ & $\mathrm{ND}$ & {$[18]$} \\
\hline Tanzania & $0.10-3.50$ & - & $5.90-87.7$ & $3.40-14.0$ & $0.1-8.9$ & - & - & {$[23]$} \\
\hline $\begin{array}{l}\text { Mutah, } \\
\text { Jordan }\end{array}$ & $0.01-129$ & & $0.54-157$ & $0.29-26.8$ & $0.02-17.5$ & $0.25-44.3$ & $3.8-106.1$ & {$[21]$} \\
\hline $\begin{array}{l}\text { Kirkuk- } \\
\text { Iraq }\end{array}$ & - & - & $9.88-65.5$ & $16.0-59.3$ & $0.92-20.4$ & $0.10-0.60$ & $1.0-13$ & {$[16]$} \\
\hline $\begin{array}{l}\text { Saudi } \\
\text { Arabia }\end{array}$ & $0.00-250$ & & $0.00-880$ & $0.30-40$ & $0.01-25$ & $0-13.40$ & $1.40-35$ & {$[9]$} \\
\hline Italy & $0.01-35.1$ & $0.00-0.6$ & $1.40-1278$ & $1.26-474$. & $0.26-75.7$ & $0.1-85.2$ & $0.4-774$ & {$[24]$} \\
\hline
\end{tabular}

\section{CONCLUSION}

This study assessed the physicochemical quality parameters of 20 brands of bottled water presently sold in Addis Ababa retail shops and supermarkets. The results showed that the bottled water samples analyzed are safe for human consumption except few brands which contained slightly higher levels of few indivividual parameters than the permissible level of WHO and CES. The physicochemical variables of the bottled drinking water studied showed large variation in different brands of bottled water which depends on the compositions of bottled water such as natural environment, the source of water composition and type of treatment/purification techniques during the production of bottled drinking water.

The number and type of parameters reported on the labels of bottled water showed a lack of uniformity. The comparison of parameters showed major cations and anions were highly variable with each brand. The concentrations of some of physicochemical parameters measured in this study were comparable to the values labeled on bottled water, whereas some other parameters were lower than and higher than values reported on the labels. The water quality index based on 15 important parameters has indicated that the bottled water samples has the lowest value of water quality index of 3.85 and the highest value of 49.2 which categorized them as excellent water quality and good water quality, respectively. In general this study recommends the regular need for a nationwide survey about the quality of waters including tap and river waters as well as groundwater and all marketed bottled waters be monitored for quality and identity by concerned authorities to safeguard consumers' health. 


\section{ACKNOWLEDGMENTS}

The authors express their gratitude to the Department of Chemistry, Addis Ababa University for providing the laboratory facilities. Elisabet Yilkal is grateful to her sponsor SIDA women's scholarship for pursuing her postgraduate study.

\section{REFERENCES}

1. Daud, K.M.; Nafees, M.; Ali, S.; Rizwan, M.; Bajwa, A.R.; Shakoor, B.M.; Arshad, U. M.; Chatha, S.A.S.; Deeba, F.; Murad, W.; Malook, I.; Zhu, J.S. Drinking water quality status and contamination in Pakistan. Res. Int. 2017, 1-19.

2. Mohsin, M.; Safdar, S.; Asghar, F.; Jamal, F. Assessment of drinking water quality and its impact on resident health in Bahawalpur City. Int. J. Human. Soc. Sci. 2013, 3, 114-128.

3. Gorde, S.P.; Jadhav, M.V. Assessment of water quality parameters: A review. Int. J. Eng. Res. Appli. 2013, 3, 2029-2035.

4. Yousaf, S.; Chaudhry, M.A. Microbiological quality of bottled water available in Lahore City. J. Pak. Med. Stud. 2013, 3, 110-112.

5. Gangil, R.; Tripathi, R.; Patyal, A.; Dutta, P.; Mathur, K. Bacteriological evaluation of packaged bottled water sold at Jaipur City and its public health significance. Veterinary World 2013, 5, 27-30.

6. Cobbina, S.J.; Duwiejuah, A.B.; Quansah, R.; Obiri, S.; Bakobie, N. Comparative assessment of heavy metals in drinking water sources in two small-scale mining communities in Northern Ghana. Int. J. Environ. Res. Public Health 2015, 12, 1062010634.

7. Werkneh, A.A.; Medhanit, B.Z.; Abay, A.K.; Damte, J.Y. Physico-chemical analysis of drinking water quality at Jigjiga City, Ethiopia. Am. J. Environ. Protect. 2015, 4, 29-32.

8. Bolawa, O.E.; Adelusi, O.S. Determination of heavy metal profile in bottled water and sachet water samples obtained from various markets in Lagos Nigeria. Environ. Pollut. Climate Change 2017, 1, 1-5.

9. Ghrefat, H.A. Classification and evaluation of commercial bottled drinking waters in Saudi Arabia. Res. J. Environ. Earth Sci. 2013, 5, 210-218.

10. Ziad, M.; Khalid, S.; Naz, A.; Saha, W.; Khan, A.; Ayaz Khan, A.; Rehman, Z. Assessment of drinking water quality in Afghan Refugee Camp, District Haripur, Pakistan. J. Sci. Tech. 2014, 38, 23-30.

11. Weldemariam, M.M. Physicochemical analysis of Gudbahri river water of Wukro, Eastern Tigrai, Ethiopia. Int. J. Sci. Res. Publi. 2013, 3, 1-4.

12. Yousaf, S.; Chaudhry, A.M. Microbiological quality of bottled water available in Lahore City. J. Pak. Med. Stud. 2013, 3, 110-112.

13. Akoteyon, I.S.; Omotayo, A.O.; Soladoye, O.; Olaoye, H.O. Determination of water quality index and suitability of urban river for municipal water supply in Lagos-Nigeria. Eur. J. Sci. Res. 2011, 54, 263-271.

14. World Health Organization (WHO) Guidelines for Drinking-Water Quality, 4th ed., World Health Organization: Geneva, Switzerland; 2011.

15. World Health Organization (WHO) Guidelines for Drinking Water Quality, 4th ed. Incorporating the First Addendum, World Health Organization: Geneva, Switzerland; 2017.

16. Hussein, E.; Radha, M.; Sabah, Z. Quality assessment of various bottled-water and tap-water in Kirkuk - Iraq. J. Eng. Res. Appli. 2014, 4, 08-15.

17. Khaniki, J.G.; Ghaderpoor, M.; Dehghan, H.M.; Shahrokh Nazmara, S. Analysis of toxic and trace metal contaminants in bottled water by using atomic absorption spectrometry. $J$. Faculty Food Eng., Ştefan Cel Mare Uni. - Suceava 2011, 10, 78-83. 
18. Mekonnen, T.Y.; Shemsu, S.A.; Rajasekhar, K.K.; Rafi, M.M. Assessment of chemical quality of major brands of bottled water marketed in Gondar Town, Ethiopia. Int. J. Innov. Pharm. Res. 2015, 6, 497-501.

19. Ensermu, M. Trends in bottled water use survey in Addis Ababa: Implication on reverse logistics of bottledwater manufacturing in Ethiopia. Int. J. Sci. Res. 2014, 3, 935-942.

20. Toma, J.J.; Ahmed, R.S.; Abdulla, Z.K. Application of water quality index for assessment water quality in some bottled water Erbil City, Kurdistan Region, Iraq. J. Adv. Lab. Res. Biol. 2013, 4, 117-124.

21. Momani, A.K. Chemical assessment of bottled drinking waters by IC, GC, and ICP-MS. Instrumentation Sci. Technol. 2006, 34, 587-605.

22. Sasikaran, S.; Sritharan, K.; Balakumar, S.; Arasaratnam, V. Physical, chemical and microbial analysis of bottled drinking water. Ceylon Med. J. 2012, 57, 111-116.

23. Mihayo, I.Z.; Mkoma, S.L. Chemical water quality of bottled drinking water brands marketed in Mwanza City, Tanzania. Res. J. Chem. Sci. 2012, 2, 21-26.

24. Dinelli, E.; Lima, A.; Albanese, S.; Birke, M.; Cicchella, D.; Giaccio, L.; Valera, P.; De Vivo, B. Comparative study between bottled mineral and tap water in Italy. J. Geochem. Exploration 2012,112, 368-389.

25. Rakotondrabe, F.; Ngoupayou, N.R.J.; Mfonka, Z.; Rasolomanana, H.E.; Abolo, N.J.A.; Ako, A.A. Water quality assessment in the Betare-Oya gold mining area (East-Cameroon): Multivariate statistical analysis approach. Sci. Total Environ. 2018, 610-611, 831-844.

26. Yegondra, K.; Puttaiah, T.E. Determinations of water quality index and suitability of an urbawater body in Shimago Town, Karnataka. Proceedings of Taal 2007: The $12^{\text {th }}$ World Lake Conference, 2008; pp. 342-346.

27. Tyagi, S.; Sharma, B.; Singh, P.; Dobhal, R. Water quality assessment in terms of water quality index. Am. J. Water Resour. 2013, 1, 34-38.

28. Barki, N.D.; Singa, K.P. Water quality assessment in terms of water quality index. Global Inst. Res. Educ. 2014, 3, 69-71.

29. Boah, K.D.; Boakye, S.; Twum, B.S.; Pelig-Ba, B.K. Mathematical computation of water quality index of Vea Dam in Upper East Region of Ghana. Environ. Sci. 2015, 3, 11-16.

30. Khare, P.D.; Dube, A.K.; Bhatia, K.R. Assessment of water quality index of Robertson Lake Jabalpur and use of test result in remote sensing application. Int. Res. J. Eng. Technol. 2016, 3, 704-708.

31. Bouslah, S.; Djemili, L.; Houichi, L. Water quality index assessment of Koudiat Medouar Reservoir, Northeast Algeria using weighted arithmetic index method. J. Water Land Develop. 2017, 35, 221-228.

32. Ansari, K.; Hemke, M.N. Water quality index for assessment of water samples of different zones in Chandrapur City. Int. J. Eng. Res. Appli. 2013, 3, 233-237.

33. Alemu, T.; Mulugeta, E.; Tadese, M. Determination of physicochemical parameters of "Hora" natural mineral water and soil in Senkele Kebele, Oromia Region, Ethiopia. Cogent Chem. 2017, 3, 1-13.

34. Kitata, R.B.; Chandravanshi, B.S. Concentration levels of major and trace metals in onion (Allium cepa L.) and irrigation water around Meki Town and Lake Ziway, Ethiopia. Bull. Chem. Soc. Ethiop. 2012, 26, 27-42.

35. Gizaw, E.; Chandravanshi, B.S.; Zewge, F. Correlation among fluoride and metals in irrigation water and soils of Ethiopian Rift Valley, Bull. Chem. Soc. Ethiop. 2014, 28, 229244.

36. Reda, H.A. Physicochemical analysis of drinking water quality of Arbaminch Town. Annals Chem. 2016, 2, 1-8.

37. Reimann, C.; Bjorvatn, K.; Frengstad, B.; Melaku, Z.; Tekle-Haimanot, R.; Siewers, U. Drinking water quality in the Ethiopian section of the East African Rift Valley data and health aspects. Sci. Total Environ. 2003, 311, 65-80. 
38. Seda, T.; Assefa, M.; Chandravanshi, B.S.; Redi, M. Levels of common ions in bottled mineral waters consumed in Addis Ababa, Ethiopia. SINET: Ethiop. J. Sci. 2013, 36, 27-40.

39. Ethiopia - World Population Review, Ethiopia Population 2018. Available at: http://worldpopulationreview.com/countries/ethiopia-population/

40. FDREMH National Drinking Water Quality Monitoring and Surveillance Strategy, Addis Ababa, Ethiopia; 2011; pp. 1-47.

41. Sima, G. Potential Sources of Heavy Metal Pollution in Drinking Water of Addis Ababa, MSc Thesis, Addis Ababa University, Addis Ababa, Ethiopia; 2011.

42. APHA, AWWA, WEF Standard Methods for the Examination of Water and Wastewater, American Public Health Association, American Water Works Association, Water Environment Federation: Washington, D.C.; 1999.

43. APHA Standards Method for the Examination Water and Waste Water, 20th ed., Method 2340-C, American Public Health Association, American Water Works Association, Water Environment Federation: Washington, D.C.; 2002.

44. APHA Standards Method for the Examination Water and Waste Water, 20th ed., Method 4500-Cl-B, American Public Health Association, American Water Works Association, Water Environment Federation: Washington, D.C.; 2003.

45. Dwivedi, S. Compliance of ponds water quality towards mathematical modules. Int. Res. J. Environ. Sci. 2017, 6, 39-42.

46. Compulsory Ethiopian Standard (CES) Drinking Water Specification, Ethiopian Standards Agency: Addis Ababa, Ethiopia; 2013.

47. Jafari, H.; Mihrossiani, H.; Kamareii, B.; Dehestani, D. Physicochemical analysis for drinking water in Kohdasht City, Lorestan, Iran. Asian J. Appl. Sci. 2008, 1, 82-92.

48. World Health Organization (WHO) Potassium Guidelines for Drinking-Water Quality, World Health Organization: Geneva, Switzerland; 2009.

49. Simeonova, V.; Stratisb, A.J.; Samarac, C.; Zachariadisb, G.; Voutsac, D.; Anthemidis, A.; Sofonioub, M.; Kouimtzis, T. Assessment of the surface water quality in Northern Greece. Wat. Res. 2003, 37, 4119-4124.

50. Miller, J.N.; Miller, J.C. Statistics and Chemometrics for Analytical Chemistry, 5th ed., Pearson Practice Hall: England; 2005; pp 55-72. 